\title{
Evolution of Leptin Structure and Function
}

\author{
Robert J. Denvera, ${ }^{a}$ Ronald M. Bonett ${ }^{c}$ Graham C. Boorse $^{d}$ \\ ${ }^{a}$ Department of Molecular, Cellular and Developmental Biology and ${ }^{b}$ Department of Ecology and Evolutionary \\ Biology, The University of Michigan, Ann Arbor, Mich., ' Department of Biological Science, The University of Tulsa, \\ Tulsa, Okla., and d Department of Life Sciences, Mesa Community College at Red Mountain, Mesa, Ariz., USA
}

\author{
Key Words \\ Leptin - Leptin receptor - Obesity - Hypothalamus • \\ Pituitary $\cdot$ Evolution
}

\begin{abstract}
Leptin, the protein product of the obese (ob or Lep) gene, is a hormone synthesized by adipocytes that signals available energy reserves to the brain, and thereby influences development, growth, metabolism and reproduction. In mammals, leptin functions as an adiposity signal: circulating leptin fluctuates in proportion to fat mass, and it acts on the hypothalamus to suppress food intake. Orthologs of mammalian Lep genes were recently isolated from several fish and two amphibian species, and here we report the identification of two Lep genes in a reptile, the lizard Anolis carolinensis. While vertebrate leptins show large divergence in their primary amino acid sequence, they form similar tertiary structures, and may have similar potencies when tested in vitro on heterologous leptin receptors (LepRs). Leptin binds to LepRs on the plasma membrane, activating several intracellular signaling pathways. Vertebrate LepRs signal via the Janus kinase (Jak) and signal transducer and activator of transcription (STAT) pathway. Three tyrosine residues located within the LepR cytoplasmic domain are phosphorylated
\end{abstract}

by Jak2 and are required for activation of $\mathrm{SH} 2$-containing tyrosine phosphatase-2, STAT5 and STAT3 signaling. These tyrosines are conserved from fishes to mammals, demonstrating their critical role in signaling by the LepR. Leptin is anorexigenic in representatives of all vertebrate classes, suggesting that its role in energy balance is ancient and has been evolutionarily conserved. In addition to its integral role as a regulator of appetite and energy balance, leptin exerts pleiotropic actions in development, physiology and behavior.

Copyright $\odot 2011$ S. Karger AG, Basel

\section{Introduction}

Two mouse strains discovered at the Jackson Laboratory in 1950 and 1965 had identical phenotypes: morbid obesity, insulin resistance, infertility and lethargy [1]. The two strains were designated obese (ob/ob) and diabetic $(d b / d b)$, and were found to be due to single gene deficiencies. A series of elegant parabiosis experiments conducted by Douglas Coleman showed that the ob/ob strain was deficient in a blood-borne factor, while the $d b / d b$ strain was deficient in the receptor for this factor [1-3]. Over forty years passed before the mouse obese gene $(o b$

\section{KARGER \\ Fax +4161306 1234 \\ E-Mail karger@karger.ch}

www.karger.com
(C) 2011 S. Karger AG, Basel

0028-3835/11/0941-0021\$38.00/0

Accessible online at:

www.karger.com/nen
Robert J. Denver

Department of Molecular, Cellular and Developmental Biology

3065C Kraus Natural Science Building, 830 N University Ave

The University of Michigan, Ann Arbor, MI 48109-1048 (USA)

Tel. +1 734936 6625, E-Mail rdenver@ umich.edu 
or Lep) was positionally cloned by Jeffrey Friedman's group and was found to encode a hormone that they named 'leptin' after the Greek word 'leptos' for thin [4]. Leptin is a member of the type I helical cytokine family, and is related to growth hormone, prolactin and the interleukins [5]. The year after leptin was identified Tartaglia et al. [6] reported the isolation of the leptin receptor gene (LepR) by expression cloning. Shortly thereafter it was confirmed that the mutation in the $d b / d b$ mouse was in the LepR gene $[7,8]$.

In mammals leptin is secreted into the bloodstream, primarily from adipocytes, and acts on the brain to regulate food intake and metabolism [4, 9]. Leptin acts on the hypothalamus to signal when the body has sufficient energy stores, thus inhibiting appetite (i.e. it functions as an 'adipostat'). The actions of leptin occur over both short and long time frames. In the short term, plasma leptin serves as a satiety signal [10], and over longer periods, daily mean plasma leptin concentration communicates long-term energy status to the brain [11]. Central leptin signaling plays a pivotal role in the regulation of metabolic activity by peripheral tissues [12-14]. The rising prevalence of human obesity and type 2 diabetes has generated intense interest in the physiological roles that leptin plays in energy balance and food intake regulation [15-19].

In mammals, leptin acts on complex neural circuitry to regulate food intake and energy metabolism $[20,21]$. Leptin receptor expression is highest in neurons within nuclei of the basomedial hypothalamus that include the arcuate (ARC), dorsomedial hypothalamic and ventromedial hypothalamic nuclei $[22,23]$. Primary targets for leptin action in the hypothalamus are two populations of neurons located in the ARC that project axons to the lateral hypothalamic area $[21,24]$. Leptin acts on ARC proopiomelanocortin (POMC)/cocaine and amphetamine related transcript (CART) neurons to increase POMC (and CART) biosynthesis which generates an anorectic signal via alpha melanocyte-stimulating hormone $(\alpha \mathrm{MSH})[24,25]$. Leptin also acts on ARC neuropeptide $\mathrm{Y}(\mathrm{NPY}) /$ Agouti-related protein (AgRP) neurons to inhibit expression of the orexigenic signals NPY and AgRP $[24,25]$. Leptin receptors have also been reported in several extrahypothalamic sites that include the midbrain and brainstem [21, 26]. Second-order neurons that synthesize thyrotropin-releasing hormone (TRH) or corticotropin-releasing factor (CRF) located in the paraventricular nucleus are regulated indirectly by leptin targets in the ARC, and thus mediate leptin's inhibitory actions on food intake, increases in thermogenesis, and increases in pituitary hormone secretion [10]. Although much less is known about the organization and regulation of feeding control centers in the brains of nonmammalian species, the data support that the basic features of mammalian feeding control circuits are present in fishes and amphibians [27-29], and that leptin engages similar neuropeptidergic pathways in the hypothalamus/preoptic area (for frogs, see [30] [C. Li and R.J. Denver, unpublished], and for fishes, see [31, 32]).

In addition to its roles in the regulation of appetite and metabolism, leptin has pleiotropic actions in development and physiology. Some of the major actions of leptin uncovered in recent years include the promotion of linear growth through its influence on energy balance, the induction of mitosis of different cell types including chondrocytes of the epiphyseal growth plate, and the stimulation of secretion of pituitary growth hormone [33]. Leptin is permissive for the onset of puberty in mammals, perhaps acting via the cellular energy sensor mammalian target of rapamycin (mTOR) [34]. It plays critical roles in neural development. $\mathrm{Ob} / \mathrm{ob}$ and $d b / d b$ mice have reduced brain weight and DNA content which, in $o b / o b$ mice, can be reversed by leptin administration [35]. The hormone has been shown to induce mitosis in different brain regions $[36,37]$ and in the hypothalamus, leptin influences the maturation of feeding control circuitry by promoting the formation of neuronal projections among hypothalamic nuclei [38]. Leptin actions also include bone development, growth and homeostasis [30, 39-42], as well as lung development and function [43], immune function $[44,45]$, thyroid function [46] and stress response [12]. A full discussion of the diversity of leptin actions is beyond the scope of this review. See the references cited above for detailed discussions of leptin actions.

\section{Molecular Evolution of Vertebrate Leptin Genes}

Shortly after the mouse Lep gene was isolated, orthologous genes were identified in human and several other mammalian species $[4,47,48]$. Many mammalian Lep genes have since been cloned, and molecular phylogenetic analysis shows that most taxa form distinct clades that largely agree with accepted mammalian orders (fig. 1). High rates of leptin evolution are apparent in some seals (Halichoerus grypus and Leptonychotes weddellii), beavers (Castor canadensis), pikas (Ochotona curzoniae), and marmosets (Callithrix jacchus). In adult seals leptin is expressed in the lung, whereas lung leptin expression in other mammals appears to occur only in the fetus [49]. 
Fig. 1. Neighbor-joining phylogram of vertebrate leptins. The alignment was conducted using Clustal W2 and based on the BLOSSUM protein weight matrix. The neighbor-joining phylogram was based on uncorrected pair-wise sequence divergence of 229 amino acid positions (including gaps). Bootstrap values subtend major, well-supported nodes $(\geq 90 \%)$ and were based on 1,000 pseudoreplicates. The tree was rooted with human growth hormone. Vertical lines on the right indicate mammalian orders and nonmammalian vertebrate classes. Due to the differential rates of leptin evolution in some mammalian lineages, taxa in the mammalian orders Carnivora, Cetartiodactyla, Rodentia, and Primates were each constrained to be monophyletic prior to the neighbor-joining analysis. Bootstrap values are not shown for the constrained nodes. Branch lengths reflect evolutionary divergence and high rates of leptin evolution are apparent in some seals (Halichoerus grypus and Leptonychotes weddellii), beavers (Castor canadensis), pikas (Ochotona curzoniae), and marmosets (Callithrix jacchus).

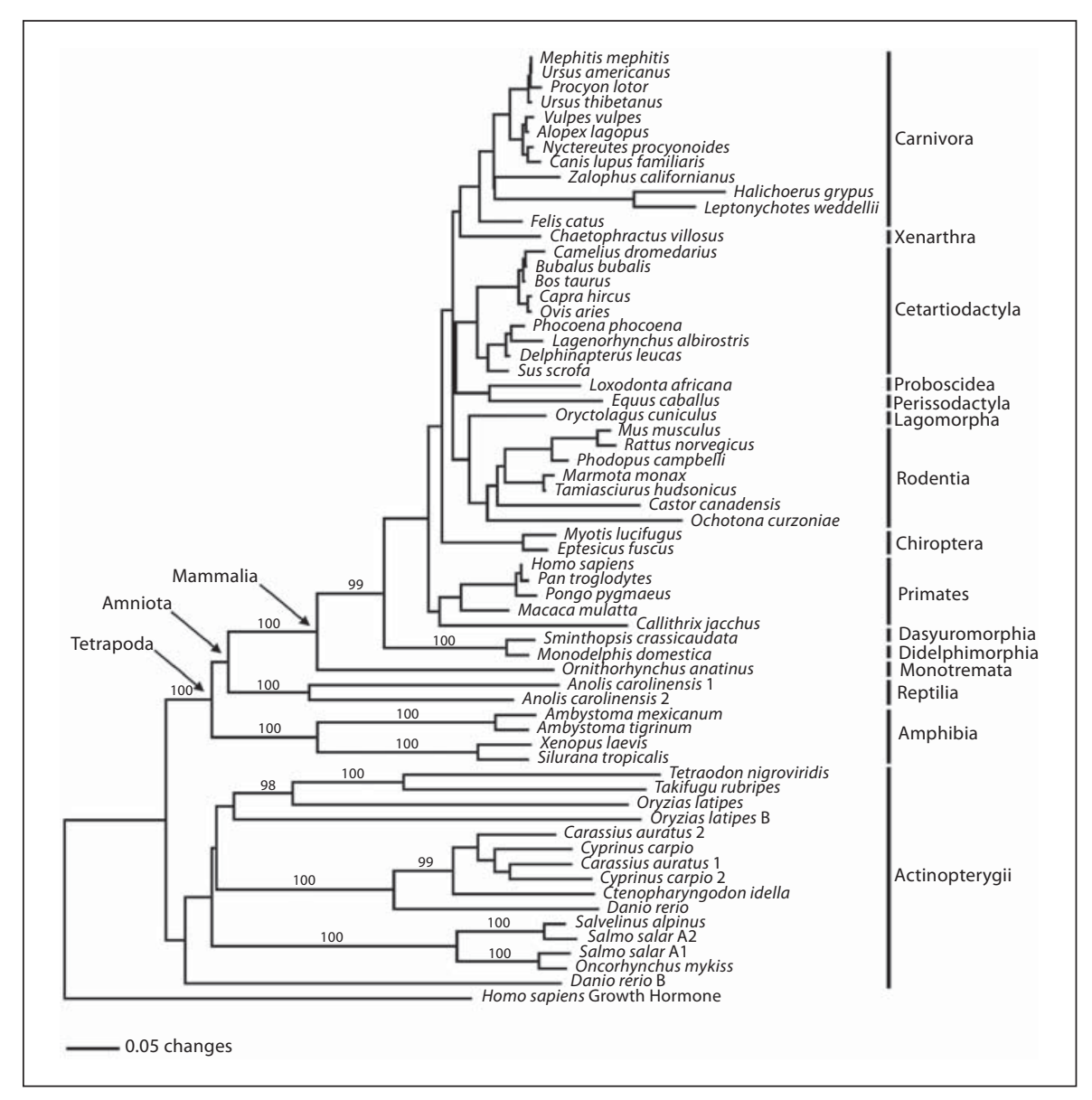

Hammond et al. [49] speculated on a role for leptin in pulmonary surfactant production in seals that may be related to the unique respiratory challenges associated with diving. Yang et al. [50] proposed that in pikas, which are non-hibernating mammals that live at high elevation or high latitudes, adaptive evolution in leptin was driven by physiological adaptation to extreme cold.

When the mouse Lep gene was first isolated the authors concluded, based on low stringency Southern hybridization of the mouse Lep probe to genomic DNA isolated from chicken, eel and fruit fly, that Lep genes were evolutionarily conserved [4]. In the decade following the discovery of the mouse Lep gene, several laboratories attempted to isolate orthologous genes from nonmammalian species using nucleic acid hybridization (e.g. library screening) or RT-PCR with degenerate primers. These attempts were uniformly unsuccessful, except in the case of the chicken, where a cDNA was isolated by RT-PCR and reported to share $95 \%$ identity to the mouse gene $[51,52]$. Subsequently, a putative Lep ortholog was isolated from turkey which also had very high sequence identity to rodent Lep genes [48]. The validity of these sequences has since been questioned [53-57]; but see counterpoint [58]. Searches of several EST databases and the chicken genome were unsuccessful in identifying a chicken Lep sequence $[53,56]$, and synteny analysis showed that the entire chromosomal region within which the chicken Lep gene should be found (on chromosome 1, which is homologous to human chromosome 7 , mouse chromosome 6) is missing [56]. Neighbor joining analysis of all known vertebrate Lep genes showed that the chicken sequence was phylogenetically nested amongst mammals and very closely related to rodents (fig. 1; the bird sequences are not included in the tree) [55]. Sharp et al. [55] pointed out that, based on the estimated frequency of synonymous substitutions due to random mutation in genes, the likelihood that the reported chicken Lep gene cDNA was correct was less than one in a million.

Despite the failure to identify avian orthologs of mammalian Lep genes, chickens have a leptin receptor in their 


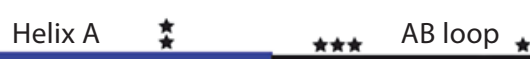

Helix B BC loop

Helix C

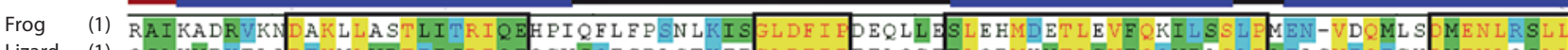

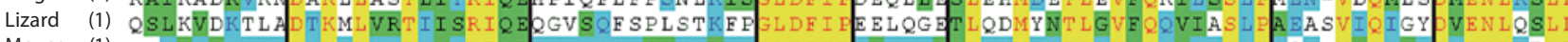

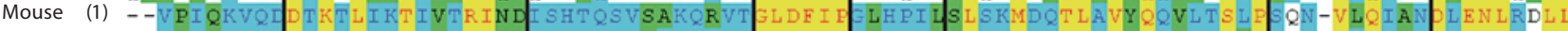

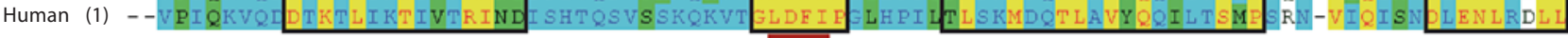

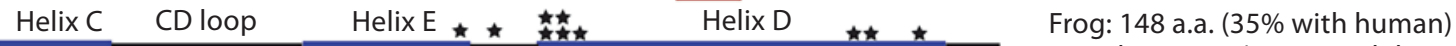

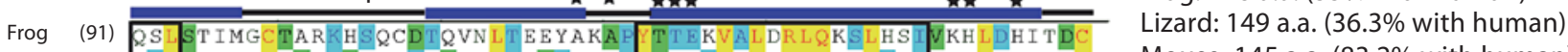

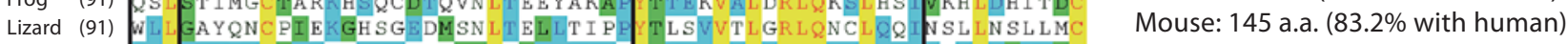
Mouse (88) HLLFSKSCSLPTSGLQKPESLDGVLEASL ISTEVVALSRLQGSLQDI Q LLDVPEC Human (88) HVLFSKSCHLPWASGLETLDSLGGVLEASG STEVVALSRLQGSLQDM WQLDLSPGC Human: 145 a.a.
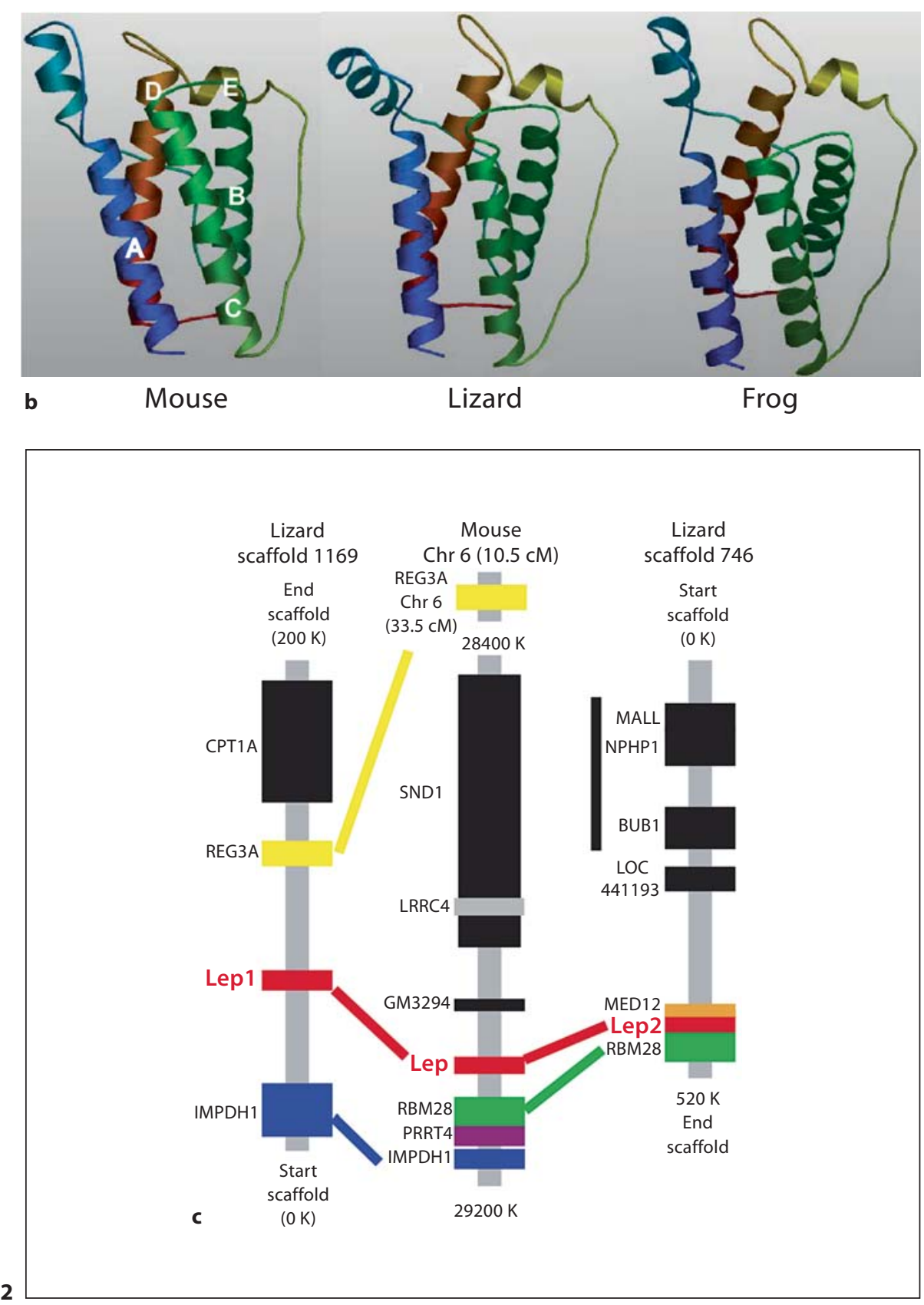
genome that is expressed, is activated to signal via the Janus kinase (Jak)/signal transducer and activator of transcription 3 (STAT3) pathway by human and frog leptins in vitro, and likely mediates the actions of administered leptin in vivo [59]. Pitel et al. [56] proposed that the gene for the ligand was lost in birds while the gene for the receptor was retained. It is possible that this occurred in some birds, but that leptin genes are retained in other avian lineages. Leptin genes were clearly present in the common ancestor of birds and squamate reptiles since the lizard, Anolis carolinensis possesses two Lep genes (discussed below). Using our predicted platypus Lep gene as the search sequence we were able to locate two candidate Lep genes within the lizard genome (online supplementary tables 1 and 2; for all online supplementary material, see www.karger.com/doi/10.1159/000328435); however, similar searches through the chicken and zebra finch genomes using platypus and lizard Lep gene sequences produced no returns. More work on other avian and reptilian species is required to determine if the Lep gene has been lost in Aves.

As discussed above, for a decade after the first isolation of Lep genes in mammals no orthologs were identified in nonmammalian vertebrates. In 2005, Kurokawa et al. [60] reported the isolation of a putative homolog of mammalian leptin in the pufferfish Takifugu rubripes. The deduced pufferfish protein is only $13 \%$ similar to human leptin (or to frog leptin - see below). Kurokawa et al. did not test whether the deduced protein product of the putative pufferfish Lep gene had biological activity commensurate with a role as a leptin.

Shortly after the publication by Kurokawa et al. [60], we reported the molecular cloning of frog (Xenopus) orthologs of mammalian Lep and Lep genes and conducted the first functional characterization of this ligand-receptor pair in a nonmammalian vertebrate [30]. The frog Lep gene encodes a predicted $16.9 \mathrm{kDa}$ protein (fig. 2). The primary amino acid sequence of frog leptin is $35 \%$ similar to human, but only $13 \%$ similar to pufferfish leptin [60]. We showed that recombinant frog leptin activated the frog LepR in vitro, signaling via STAT3, and frog leptin was potently a norexigenic when injected intracerebroventricularly into juvenile frogs [30]. Boswell et al. [61] isolated a cDNA for a putative Lep ortholog in the tiger salamander Ambystoma tigrinum that shares $60 \%$ identity with frog leptin.

Sequences orthologous to mammalian Lep genes have been described in several fish species based on genomic analyses [60] and RT-PCR cloning [31, 32, 57, 62-64]. Deciphering the molecular phylogeny of fish Lep genes is complicated by the fact that multiple, and sometimes highly divergent, copies have been identified in several species. These duplicates may have resulted from historical events such as the whole-genome duplication that occurred early in the teleost lineage [65], or the additional genome duplication event that occurred later in some teleost lineages leading to tetraploidy (e.g. salmonids [66]).
Fig. 2. Comparison of the amino acid sequences and structures of some tetrapod leptins. a Amino acid alignment of frog (Xenopus laevis; AY884210), lizard (Anolis carolinensis; Lep1; online suppl. table 1), mouse (Mus musculus; AAA64564) and human (Homo sapiens; AAA60470) leptin. The alignment colors are as follows: red character on yellow background $=$ consensus residue derived from a completely conserved residue at a given position; blue character on cyan background = consensus residue derived from a block of similar residues at a given position; black character on green background $=$ consensus residue derived from the occurrence of greater than $50 \%$ of a single residue at a given position; black character on white background $=$ non-similar residues [83]. Boxed regions are the most highly conserved sequences among tetrapod leptins. The indicated helices and loop structures are based on Zhang et al. [145]. Amino acids with two stars above them are residues in mouse leptin that when mutated lead to loss of biological activity [85]. Note that these amino acids tend to be conserved among tetrapod leptins. Amino acids with one star above are residues in mouse leptin that when mutated lead to partial loss of biological activity [85]. In most cases these amino acids show low conservation among tetrapod leptins. Red bars underneath the alignment indicate amino acids that when mutated cause the hormone to lose receptor activation function but to retain receptor binding activity, thereby generating an antagonist (LDFI - mouse a.a. 38-43; ST - mouse a.a. 120, 121) [86]. The two conserved cysteines are indicated by arrows. The alignment was conducted using the Align X module of Vector NTI Advance 11 software (Invitrogen, Carlsbad, Calif., USA). b Ribbon diagrams showing secondary and tertiary structures of mouse, lizard and frog leptins. Three-dimensional modeling was done using the ProModII program at the SWISS-MODEL automated protein modeling server, and was based on the human leptin (1AX8.pdb) Protein Data Bank structure file. c Synteny mapping of leptin genes from mouse and lizard. Gene position on the mouse chromosome was determined by NCBI sequence viewer of Mus musculus chromosome 6, reference assembly (C57BL/6J). Gene positions on the lizard scaffolds were determined using the UC Santa Cruz Genome Browser of Anolis carolinensis (Feb. 2007 AnoCar v. 1.0). Only limited gene arrangement information is available for these lizard scaffolds because of their short length. The vertical black bar to the left of the lizard scaffold 746 indicates a block of neighboring genes (MALL, NPHP1 and BUB1) found on mouse chromosome 2 (73 cM). 
Differential rates of gene loss or divergence in different lineages, the limited sequence data now available, and the tenuous phylogenetic placement of divergent fish leptins are also challenging our understanding of the history of this gene in fishes. Some fishes (e.g. zebrafish and medaka) $[62,67]$ have two divergent types of Lep genes (designated A and B; fig. 1) that may have arisen from the initial whole-genome duplication event. Alternatively, these may have resulted from clade-specific gene duplications with subsequent divergence of one of the two copies. Multiple copies of 'A lineage' Lep genes have been isolated from Atlantic salmon, common carp, and goldfish, with minimal divergence among the paralogs and likely result from lineage-specific tetraploidizations in salmonids [62, 68] and cyprinids [57, 63, 69, 70]. Takifugu rubripes, a teleost species that has undergone drastic genome reduction, appears to have retained only one Lep gene [60].

We searched the genome of the lizard Anolis carolinensis and identified, for the first time, Lep and LepR genes in a reptile. Anolis has two putative Lep genes (designated Lep1 and Lep2; online suppl. table 1; [71]). The predicted mature Lep1 protein of the lizard is 149 amino acids in length and shares $35.6 \%$ amino acid sequence identity with human leptin. The lizard Lep2 gene has multiple, single nucleotide deletions at the end of exon 3 , which results in a frame shift. This causes the predicted Lep2 mature protein to diverge from Lep1 after position 117; the Lep2 protein is predicted to be 192 amino acids. The two predicted lizard leptin proteins are $60.7 \%$ identical in the first 117 amino acids.

We conducted synteny mapping of genes neighboring mouse Lep on chromosome 6 and this supported that the two lizard Lep genes are orthologs of mouse Lep (fig. 2c). The lizard Lep1 gene resides in a homologous genomic region to mouse Lep. The lizard Lep2 gene resides in a genomic region homologous to mouse chromosome 2; the lizard Lep2 gene likely arose through a recombination event (that included gene RBM28). Preliminary results suggest that lizard Lep1 mRNA is expressed in several tissues but Lep2 mRNA is not expressed [71]. The lizard Lep1 can activate LepRs: we made recombinant lizard Lepl in E. coli and found that it activates mouse and frog LepRs in transient transfection assay with potency comparable to the homologous leptins [L. Lavner, A. Dziuba, G.C. Boorse and R.J. Denver, unpublished].

Prior to the isolation of nonmammalian Lep genes, several groups used mammalian reagents (recombinant mouse leptin, antibodies to mouse leptin or leptin receptor) to study leptin biology in nonmammalian species [27, 72-77]. In the goldfish and a lizard, injections of recom- binant mammalian leptin reduced food intake, which was consistent with the existence of a leptin-like protein in nonmammalian species that functions in energy balance regulation $[27,77,78]$. However, mammalian leptin failed to affect food intake in several other fish species [27]. Some investigators have used (and continue to use) antibodies to mouse leptin to investigate the tissue distribution and expression of leptin in nonmammalian species $[27,79-81]$. Given the low conservation of the primary structure of leptins from different vertebrate classes (fig. 2), we suggest that results obtained with heterologous immunological reagents should be interpreted with caution. On the other hand, despite low primary sequence identity, leptins from different species are active on heterologous receptors, although the potency varies [30, 59]; see also [82] for activity of pufferfish leptin on proliferation of BAF $/ 3$ cells stably transfected with the long form of human leptin receptor. Therefore, studies in which murine leptin was used in nonmammalian species could point to a physiological role for the endogenous, native leptins, but this must be verified once the homologous hormones become available.

\section{Conserved Structural Features of Vertebrate Leptins} Related to Their Function

When the crystal structure of human leptin was solved, it was found to have four $\alpha$ helix bundle folds, closely resembling the structures of other class I helical cytokines [5]. Like other class I helical cytokines, vertebrate leptins show significant divergence in their primary structures, but are nevertheless highly similar in their predicted secondary and tertiary structures (modeling based on the crystal structure of human leptin; fig. 2b) $[57,60,63]$. Natural selection tends to maintain the intrinsic stability of secondary and tertiary structures of proteins [83], and this is illustrated well by the class I helical cytokines [5].

Leptin resembles other class I helical cytokines in that it has four antiparallel helices designated A-D, but it differs in that it has a small helical segment designated helix E found in the loop linking helices C and D (fig. 2b). All vertebrate leptins have a pair of conserved cysteine residues that in human leptin have been shown to form a disulfide bridge required for full biological activity [30, 60, 84] (fig. 2a). Three receptor interacting sites on mammalian leptins have been mapped by mutational analysis [85]. Site I is located on the face of helix D, site II is on helices A and C, and site III at the N-terminus of helix D. Each of these regions shows some degree of conservation of primary amino acid sequence among vertebrate leptins 
(fig. 2a). Amino acid substitutions that resulted in a significant reduction in biological activity of the hormone were likely selected against, as these positions tend to be completely or mostly conserved across tetrapods (indicated by double stars above sequences in fig. 2a).

There are other regions of vertebrate leptins located outside of the three identified receptor binding sites that show a high degree of sequence identity. For example, there is conservation in helix $\mathrm{B}$ and the $\mathrm{BC}$ loop. The most highly conserved stretch of amino acids is the six residue sequence GLDFIP (positions 38 to 43 in human leptin); this sequence is completely conserved among tetrapods (fig. 2a). Mutation of LDFI to all alanines generates an antagonist (a leptin 'mutein') that binds to the LepR but fails to activate it [86]. Although this sequence is not a part of the receptor binding sites, it is required for activation of the LepR and has apparently been subject to strong stabilizing selection. Elinav et al. [87] produced a PEGylated form of the LDFI mutein that has enhanced antagonist activity in vivo due to reduced clearance. We recently engineered a frog leptin LDFI mutein and found that it also has antagonist activity on the frog LepR when tested in vitro [C. Pelletier, A. Dziuba, M. Cui and R.J. Denver, unpublished]. The GLDFIP sequence is absent in fish leptins [85] and may indicate a different mechanism for binding to and activation of the LepR compared with tetrapods. Other amino acids that have been mutagenized to generate a leptin antagonist are the $\mathrm{S}$ and $\mathrm{T}$ residues at positions 120 and 121, respectively, of mouse leptin [86].

As mentioned above, there is considerable divergence in primary amino acid sequence among vertebrate leptins. However, their secondary and tertiary structures, and key amino acids required for biological activity, particularly among tetrapods, are evolutionarily conserved (it should be noted that the predicted structures of nonmammalian leptin are based on models of the crystal structure of human leptin). This conservation parallels the conservation of key structural elements within the two cytokine receptor homology domains (CHDs) of vertebrate LepRs [88] (discussed below; fig. 3). The significance of this conservation is highlighted by the finding that heterologous hormone-receptor pairings among tetrapod leptins and LepRs leads to productive receptor activation, often with similar potency to the homologous hormone. For example, recombinant leptins of frog and lizard activated the mouse LepR with equal potency to human leptin. Similarly, human and lizard leptins activated the frog LepR, although with lower potency than frog leptin [30] [L. Lavner, A. Dziuba, G.C. Boorse and R.J. Denver, unpublished].

Comparative Biology of Leptin

\section{Tissue Sites of Leptin Production}

In mammals, the major sites of Lep mRNA expression are adipose tissue, stomach and liver [89-92]. Lep mRNA is expressed at lower levels in heart, placenta and fetal tissues $[93,94]$, the pituitary gland, where leptin may modulate pituitary hormone secretion [95-97], and in the brain [98] where the hormone can influence neural development $[36,99,100]$ and cognitive function in the adult [101]. In nonmammalian species, Lep mRNA appears to be more widely expressed compared with mammals, although the major sites of expression may differ among taxa [30]. For example, in the frog, Lep mRNA expression levels were highest in brain, pituitary and heart [30]. The Lep gene is expressed throughout the frog GI tract and in the two major sites of expression in mammals, liver and fat, although the levels of expression in frog liver and fat were lower than in some other organs that express leptin. Widespread tissue expression of the Lep gene has also been reported in several fishes [63]. In salmon, the highest Lep mRNA expression (sLepA1) was found in the brain, liver, white muscle and ovary [63]. Many ectothermic species express the Lep gene in liver $[30-32,57,60,62-64]$, and so this organ may be a major source of circulating leptin, and a site for nutritional regulation of leptin production $[57,63]$.

\section{Molecular Evolution of Vertebrate Leptin Receptor Genes}

The actions of leptin are mediated by hormone binding to the LepR located in the plasma membrane. The LepR belongs to the class I helical cytokine receptor family [102] (fig. 3). These receptors all signal via the Jak/ STAT pathway [103]; although other signaling pathways may be engaged by the LepR, as discussed below [104]. The Jak (Jak2) and STAT (STAT3 and STAT5) proteins important for LepR signaling (and signaling by other hormone-activated cytokine receptors) are highly conserved across vertebrate taxa, much more so than Jaks or STATs involved with immune signaling [105]. In mammals, six isoforms of the LepR (LepRa-f) generated by alternate splicing of transcripts derived from a single $L e p R$ gene have been identified [12]. All LepR isoforms have a common extracellular ligand binding domain. The long form of the LepR (LepRb) has an approximately 300 amino acid cytoplasmic tail that mediates intracellular signaling upon leptin binding. The LepRa, $-\mathrm{c},-\mathrm{d}$ and -f have short $(\sim 30-40)$ amino acid cytoplasmic extensions, while the LepRe lacks transmembrane and cyto-

Neuroendocrinology 2011;94:21-38 
Fig. 3. Neighbor-joining phylogram of cytokine receptor homology domains (CHD) from group 2, class 1 cytokines [102]. The alignment was conducted using Clustal W2 and based on the BLOSSUM protein weight matrix. The neighbor-joining phylogram was based on uncorrected pairwise sequence divergence of 218 amino acid positions (including gaps). Bootstrap values subtend major, well-supported nodes ( $\geq 90 \%)$ and were based on 1,000 pseudoreplicates. Homo sapiens (Hs), Mus musculus $(\mathrm{Mm})$, and Danio rerio (Dr) were used as representative taxa for glycoprotein 130 (GP130), GP130-like monocyte receptor (GLMR), granulocyte-CSF (GCSFR), interleukin receptors (ILR), leukemia inhibitory factor receptor (LIFR), and oncostatin $\mathrm{M}$ receptor (OSMR). The two $\mathrm{CHDs}$ of leptin receptors are monophyletic. Leptin receptor taxa are the same as those used for figure 4 . Only single representatives were included for each of the mammalian orders. The leptin receptor CHD-1 clade is red and the leptin receptor CHD-2 clade is blue.

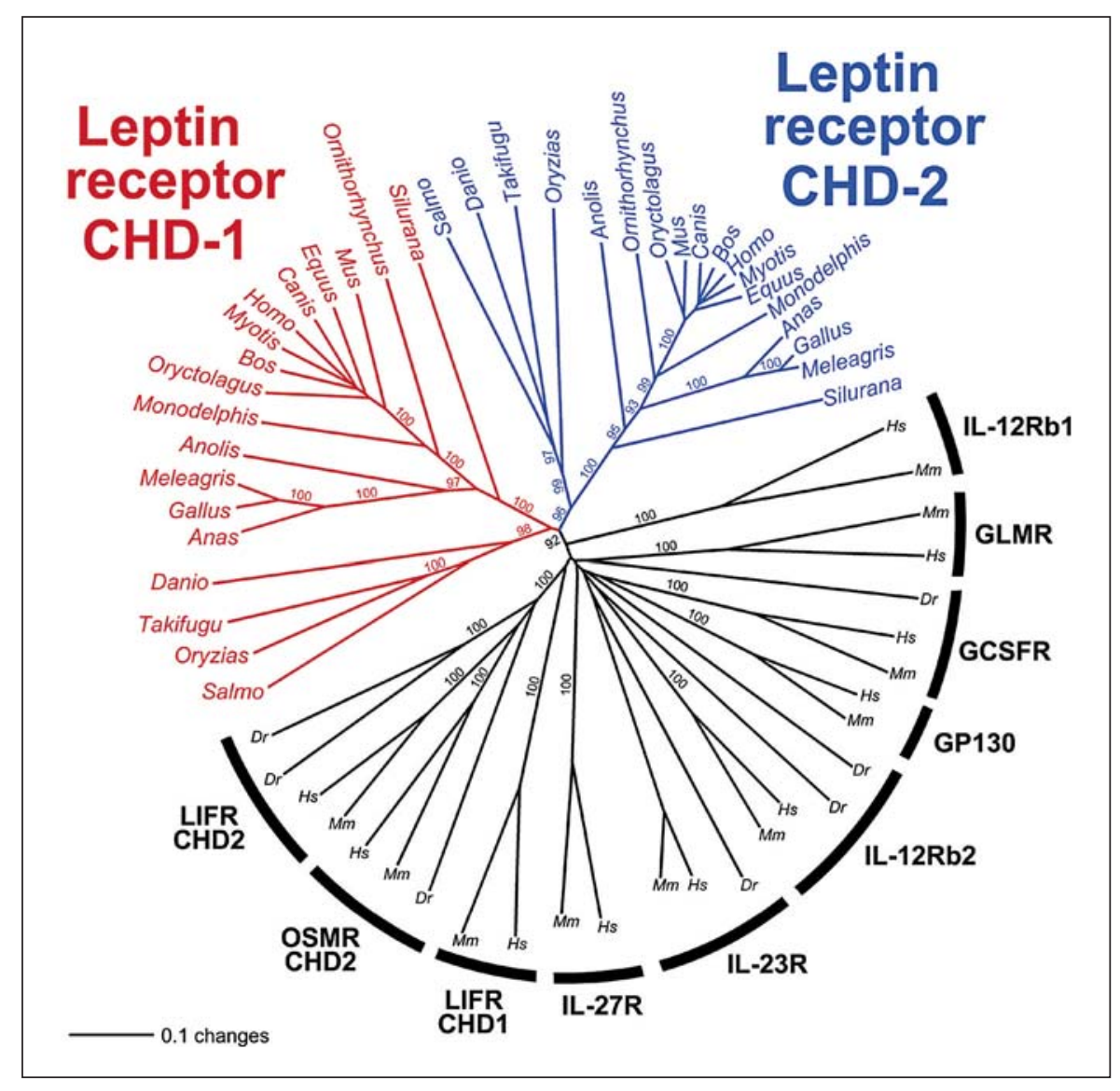

plasmic domains and may function as a secreted leptin binding protein. The LepRb is the only isoform that contains intracellular tyrosine residues necessary for signaling; the physiological functions, if any, for other LepR isoforms are unknown.

The leptin receptor has been isolated by molecular cloning, or predicted based on genome sequence in nine mammals, three birds, a reptile (lizard, Anolis carolinensis), an amphibian (frog, Silurana (Xenopus) tropicalis) and four fishes, although partial sequence data is available for other species (fig. 4; table 1; online suppl. table 2). Phylogenetic analysis of LepR tracks accepted vertebrate phylogeny well with respect to the monophyly of the classes and the relationships among them (fig. 4). The rate of LepR evolution (averaged across the whole gene) appears to be constant in different vertebrate lineages. LepR is a group 2, class 1 , helical cytokine receptor [102]. This is based partly on the structure of its CHDs. Our phylogeny based on CHDs from a diversity of vertebrae LepRs shows that the two CHDs of LepR (CHD1 and CHD2) are each monophyletic, and are sister clades with respect to other group 2, class 1, helical cytokine receptors (fig. 3). This indicates that the CHD duplication in LepR occurred after this gene was distinct from other cytokine receptors, but prior to the divergence of fishes and tetrapods. The chicken [106] and frog [S. Grommen and R.J. Denver, unpublished] may produce truncated LepR isoforms. Atlantic salmon have five LepR isoforms, one that is similar to mammalian LepRb, one that possesses the transmembrane domain but lacks most of the cytoplasmic tail, and three that may be secreted forms [63]. More data are needed to assess the production and variation of LepR isoforms among vertebrates and to determine their biological roles.

The structural features of the extracellular ligand binding domain that govern interactions between leptin and the LepR have been and continue to be investigated due to the potential to develop selective LepR agonists and antagonists of therapeutic value [88]. Rønnestad et al. [63] recently compared the structures of the LepR extracellular domains of several vertebrate species from fish to mammal. Here we focus on structural features of the cy- 
Fig. 4. Neighbor-joining phylogram of vertebrate leptin receptors. The alignment was conducted using Clustal W2 and based on the BLOSSUM protein weight matrix. The neighbor-joining phylogram was based on uncorrected pairwise sequence divergence of 1,242 amino acid positions (including gaps). Bootstrap values subtend major, well-supported nodes $(\geq 90 \%)$ and were based on 1,000 pseudoreplicates. Vertical lines on the right indicate mammalian orders and nonmammalian vertebrate classes.

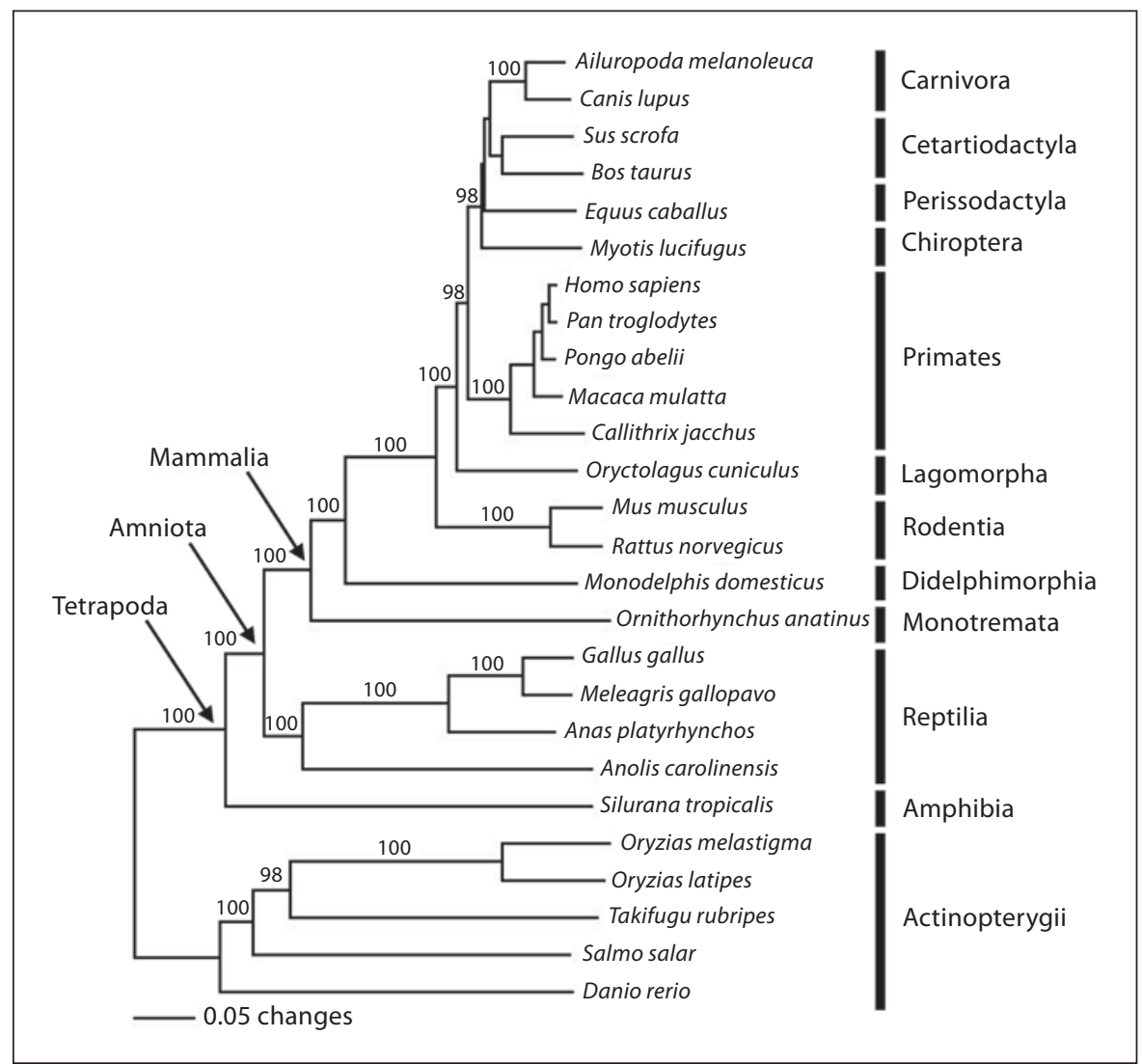

toplasmic domain of the LepR that are necessary for intracellular signaling.

Jak 2 is constitutively associated with the mouse LepRb at membrane-proximal residues located within the cytoplasmic domain [107] (fig. 5). The location of these sites has been mapped by deletion analysis $[107,108]$. Jak 2 recruitment to LepRb depends on cytoplasmic domain amino acids PXP (a.a. 14-16) located within a region called Box 1 that shares features with other class I cytokine receptors $[102,109]$. The Box 1 homology motif is highly conserved among vertebrate LepRs (fig. 6). Also necessary are amino acids 19-24 (CSWAQG), which are completely conserved among tetrapods and largely conserved among fishes; and amino acids $31-48$. There is flexibility in the sequence requirements for amino acids $37-48$, but the sequence of amino acids $31-36$ plays a critical role in Jak2 activation [107]. The latter sequence shows some degree of conservation among vertebrates, while the former sequence is only conserved within tetrapods (fig. 6a, c). Bahrenberg et al. [108] showed that the two hydrobic residues, $\mathrm{L}$ and $\mathrm{F}$, located at positions 36 and
37 were indispensable for receptor signaling. These two residues are completely conserved among tetrapods and largely conserved in fishes (indicated by stars above the sequences in fig. 6).

Two putative Box 2 homology motifs were proposed for the LepRb (intracellular amino acids 49-60 and 202$213[107,109,110]$, shown in figure 6a with question marks) but were found not to be required for Jak2 signaling $[107,108]$. However, the relatively high evolutionary conservation of residues within the first putative Box 2 motif (a.a. 49-60) suggests that it has some, as yet undiscovered role in LepR signaling. The second putative Box 2 motif (a.a. 202-213) shows very little sequence conservation across taxa. The Box 3 homology motif is critical for recruitment and activation of STAT3 $[109,111]$.

Hormone binding induces Jak2 autophosphorylation, which increases the Vmax of the kinase, and Jak2 then phosphorylates three tyrosine residues located in the cytoplasmic domain of LepRb [111] (fig. 5 and 6). These three tyrosine residues are conserved among all vertebrates that have been studied. Phosphorylation of $\mathrm{Y}^{985}$ in 
Table 1. Species, common name, accession number, and length of vertebrate leptin (Lep) and leptin receptor (LepR) proteins used in phylogenetic analyses

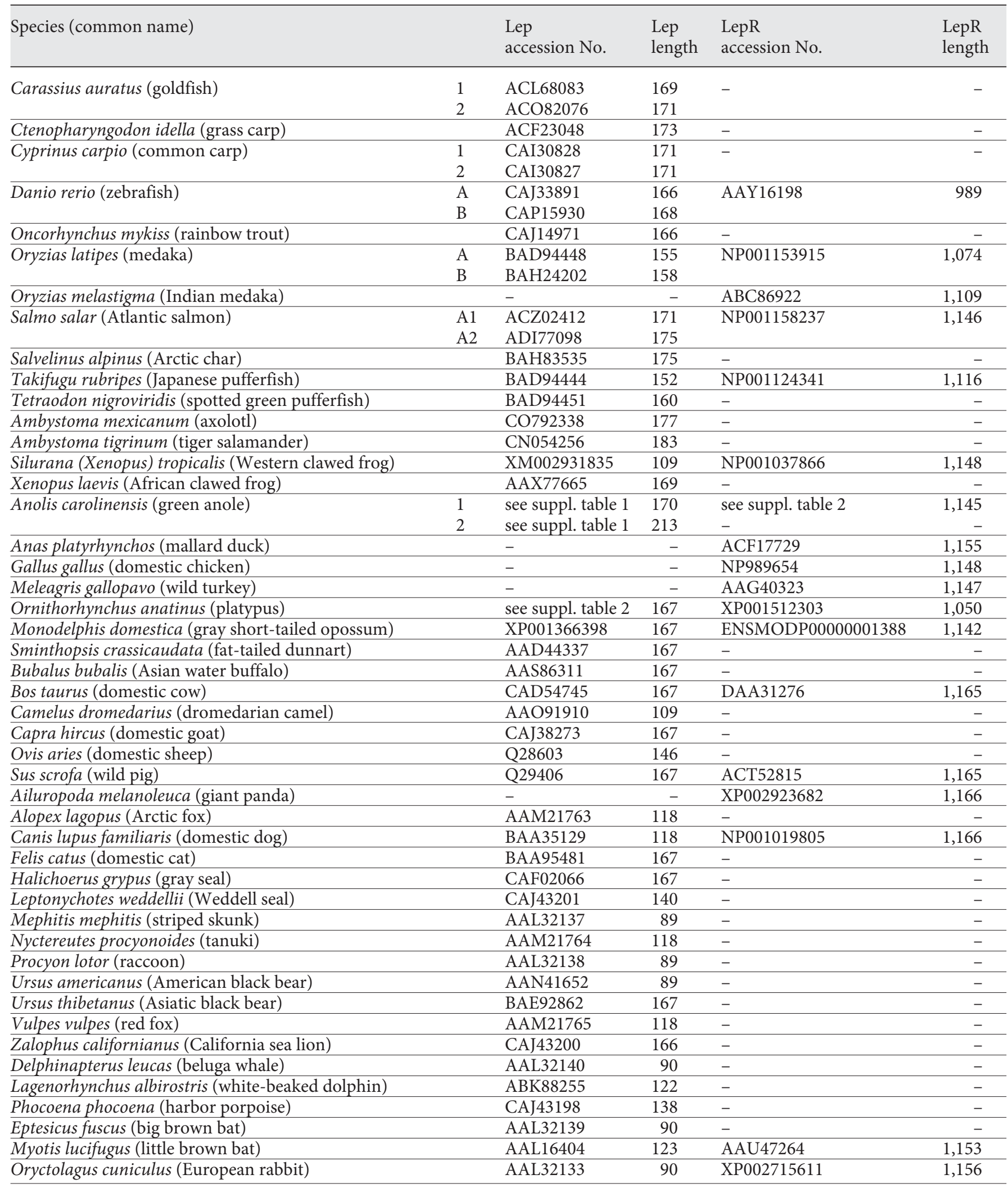


Table 1 (continued)

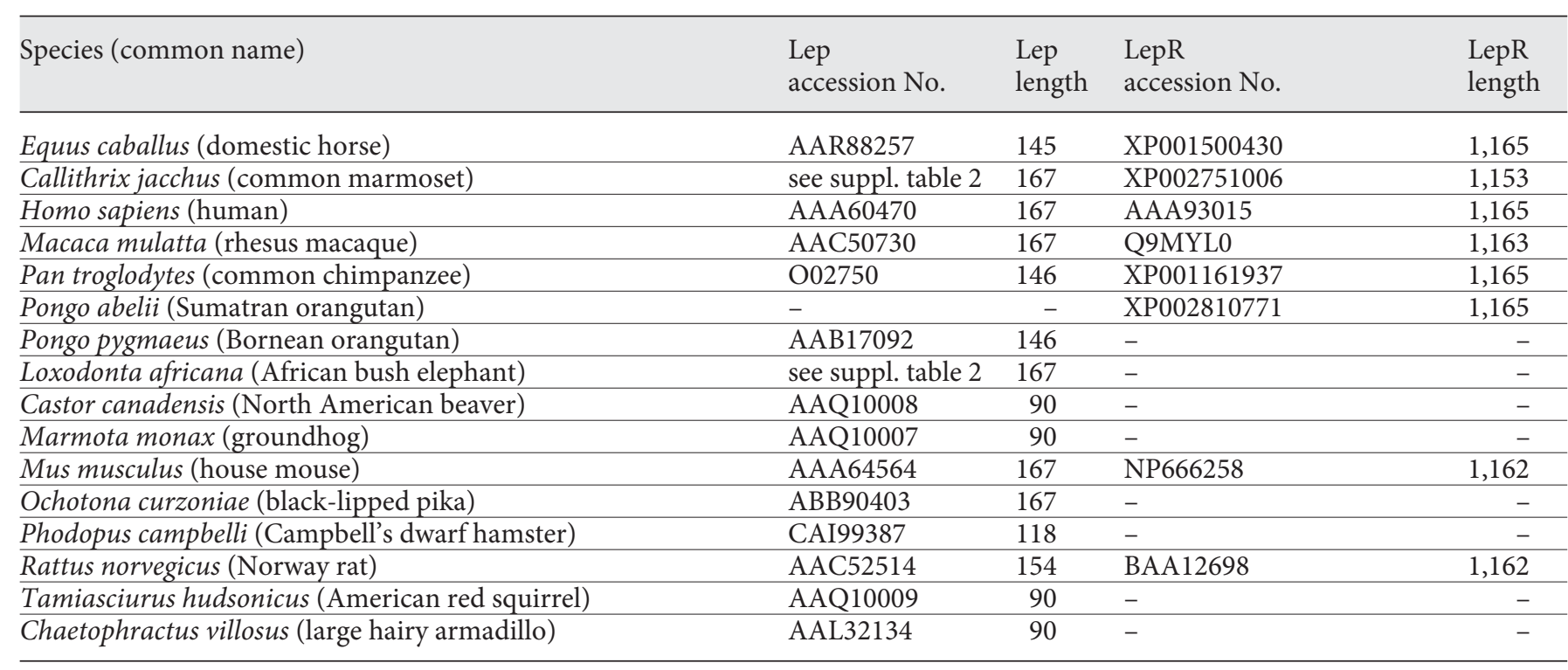

mouse LepRb leads to recruitment of $\mathrm{SH} 2$-containing tyrosine phosphatase-2 (SHP2; $[112,113]$ which then promotes activation of the extracellular signal-regulated kinase (ERK) cascade [104]. Leptin activation of the ERK cascade has been linked to phosphorylation of ribosomal protein S6 and cap-dependent protein translation [104]. The $\mathrm{Y}^{985}$ site also mediates feedback inhibition of the LepRb by suppressor of cytokine signaling 3 (SOCS3) [114]. The residues immediately following $\mathrm{Y}^{985}$ are completely conserved among tetrapods (consensus sequence YAT; fig. 6a) but not among fishes (fig. 6b).

Phosphorylation of $\mathrm{Y}^{1077}$ leads to recruitment and phosphorylation of STAT5 [115] (fig. 5). Mutation of $Y^{1077}$ leads to obesity in mice, but the molecular physiological pathways regulated by STAT5 are unclear [104]. Phosphorylation of $\mathrm{Y}^{1138}$ leads to recruitment and phosphorylation of STAT3 [104]. The STAT3 pathway has been shown to be critical for mediating leptin actions on food intake, glucose metabolism, and weight gain, but does not influence fertility [116]. The Box 3 sequence surrounding $\mathrm{Y}^{1138}$ that forms the binding site for STAT3 is evolutionarily conserved from fishes to mammals (fig. 6c). The consensus STAT3 binding sequence is considered to be YXXQ; however, the complete conservation of the $\mathrm{P}$ in position 3, and the following two residues FQ (FR in fishes) suggests that the critical residues in the LepR are YXPQFQ/R. This site has been functionally conserved through tetrapod evolution as evidenced by the finding that the frog LepR activated STAT3 signaling when tested in transient transfection assay [30], leptin injection increased pSTAT3 immunoreactivity in frog brain [C. Hu, C. Pelletier and R.J. Denver, unpublished], and mutation of $\mathrm{Y}^{1127}$ of the frog LepR (homologous to $\mathrm{Y}^{1138}$ in the mouse LepR) abrogated STAT3 signaling [A. Dziuba and R.J. Denver, unpublished]. Activation of STAT3 leads to the upregulation of SOCS3, which binds to $\mathrm{Y}^{985}$ on LepRb and inhibits signaling [104]; fig. 6). The phosphoinositol 3 kinase and mammalian target of rapamycin pathways are also engaged by LepRb signaling but the mechanisms for their activation are poorly understood [104].

\section{Tissue Sites of Leptin Receptor Expression}

In mammals the LepRb is highly expressed in the hypothalamus and at lower levels in several other tissues including liver [91], kidney, lung [117], stomach [118], pancreatic $\beta$ cells [119], and immune cells [120]. Leptin's role in energy balance/body weight control is mediated by LepRb expressed in the brain $[104,121]$.

In the few nonmammalian species that have been studied, LepR mRNA is as highly expressed in the brain as it is in mammals [30,63, 122]. Liu et al. [122] reported that LepR mRNA expression was restricted to the adult zebrafish hindbrain and hypothalamus. Using increased pSTAT3 immunoreactivity following leptin injection we mapped biologically active LepR in frog to the anterior preoptic area (location of neurosecretory neurons in the 


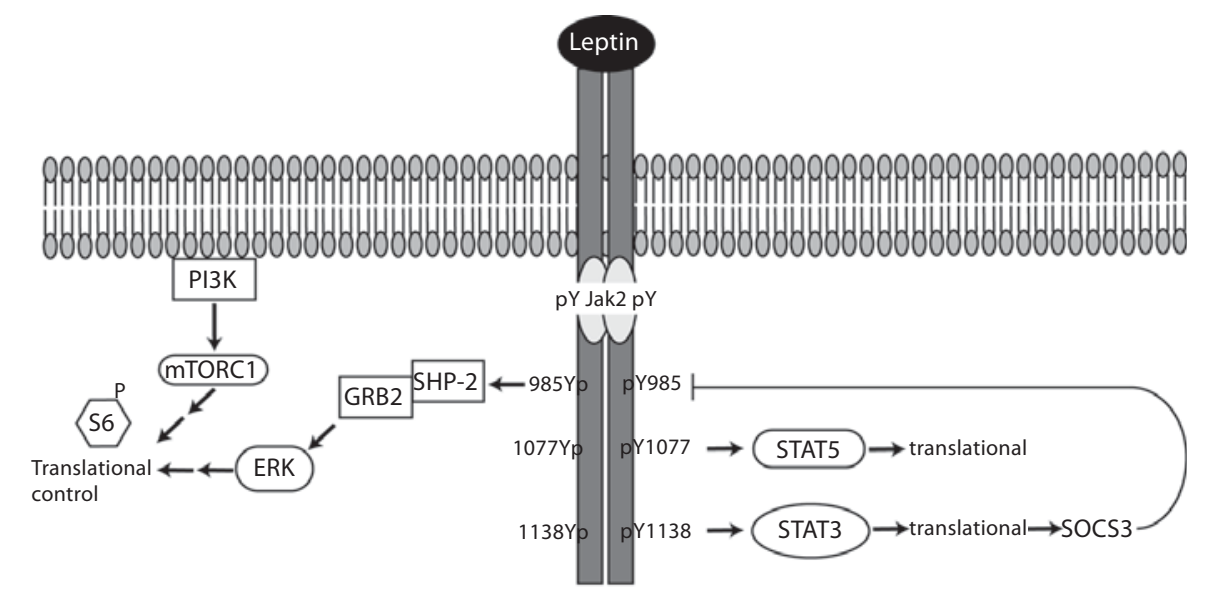

Fig. 5. Intracellular signaling pathways engaged by the leptin receptor (mouse LepRb). The LepRb forms a homodimer in the membrane. Leptin binds to the extracellular domain leading to a conformational change in the receptor, activating Janus kinase 2 (Jak2) which then phosphorylates (designated by 'p') three evolutionarily conserved tyrosine residues within the cytoplasmic domain of LepRb. The $\mathrm{Y}^{985}$ is required for activation of the SH2containing tyrosine phosphatase-2 (SHP2)/extracellular signalregulated kinase (ERK) cascade (activation of ERK via growth factor receptor binding protein 2 - GRB2) which leads to the phosphorylation of ribosomal protein S6 and increased translation. $\mathrm{Y}^{1077}$ is required for signaling by signal transducer and activator of transcription 5 (STAT5), while $\mathrm{Y}^{1138}$ mediates STAT3 signaling. STAT3 transactivates the suppressor of cytokine signaling 3 (SOCS3) gene, and SOCS3 mediates negative feedback on LepRb signaling via $\mathrm{Y}^{985}$. The LepRb also activates the phosphatidylinositol 3 kinase (PI3K) and mammalian target of rapamycin 1 (mTORC1) pathways, but the mechanism is not understood. The diagram is based on figure 1 of Villanueva and Myers [104].
Fig. 6. Conserved structural features of the cytoplasmic domains of vertebrate leptin receptors. The alignment color scheme is as described in the legend of figure 2. a Alignment of tetrapod LepR cytoplasmic domains. Shown are frog [Silurana (Xenopus) tropicalis; NP001037866] lizard (Anolis carolinensis; online suppl. table 2), chicken (Gallus domesticus; NM204323), mouse (Mus musculus; AAC52705) and human (Homo sapiens; AAB09673). Box homology motifs 1, 2 and 3 are regions conserved among class I helical cytokine receptors [102]. Sequences within the Box 1 homology motif are important for Jak2 recruitment and activation $[107,108]$. The existence, position and function of the putative Box 2 homology motif in vertebrate LepRs is uncertain ([107, 108]; the two predicted Box 2 homology motifs are shown with question marks). A region immediately $\mathrm{N}$-terminal to the second Box 2 homology motif shows evolutionary conservation and is indicated by the dotted green box. Blue bars beneath the sequence alignments correspond to amino acids 13-24 (long bar) and 31-36 (short bar) in the mouse LepRb (numbering from the beginning of the cytoplasmic domain) that have been shown to be critical for Jak2 binding and activation [107]. The red bar corresponds to amino acids $37-48$ which have also been shown to function in Jak2 activation but whose sequence requirements are more flexible than amino acids 31-36 [107]. Stars above the sequences indicate the two hydrophobic residues, leucine and phenylalanine, located at positions 36 and 37 shown by Bahrenberg et al. [108] to be indispensable for receptor signaling. The Box 3 homology mo- tif is critical for recruitment and activation of STAT3 [109, 111]. The asterisks designate conserved cysteine residues. Arrows show conserved tyrosine residues in the mouse LepRb necessary for signaling via $\mathrm{SH} 2$-containing tyrosine phosphatase-2 ( $\mathrm{Y}^{985}$ mouse; $\mathrm{Y}^{986}$ human; $\mathrm{Y}^{976}$ chicken; $\mathrm{Y}^{973}$ frog), STAT5 ( $\mathrm{Y}^{1077}$ mouse; $\mathrm{Y}^{1079}$ human: $\mathrm{Y}^{1071}$ chicken; $\mathrm{Y}^{1066}$ frog) and STAT3 ( ${ }^{1138}$ mouse; $\mathrm{Y}^{1141}$ human; $\mathrm{Y}^{1129}$ chicken; $\mathrm{Y}^{1127}$ frog). The comparable positions in the lizard LepR could not be fixed because the precise N-terminus of the protein has not yet been determined. b Alignment of three fish LepR cytoplasmic domains: salmon (Salmo salar; AB489201), zebrafish (Danio rerio; DQ007541) and pufferfish (Takifugu rubripes; AB385663). Shown are the predicted Box 1, 2 and 3 homology domains. The dotted green box corresponds to the conserved region in tetrapod LepRs that is $\mathrm{N}$-terminal to the second putative Box 2 motif. The three conserved tyrosine residues are indicated by the arrows (with the corresponding amino acid position for the mouse LepRb). c Alignment of the LepR cytoplasmic domains of a representative teleost fish (zebrafish - Danio rerio; DQ007541), nonamniote tetrapod [amphibian - Silurana (Xenopus) tropicalis] and amniote tetrapod (human - Homo sapiens). Shown are the predicted Box 1, 2 and 3 homology domains. The dotted green box corresponds to the conserved region in tetrapod LepRs that is N-terminal to the second putative Box 2 motif. The three conserved tyrosine residues are indicated by the arrows (with the corresponding amino acid position for the mouse LepRb). 


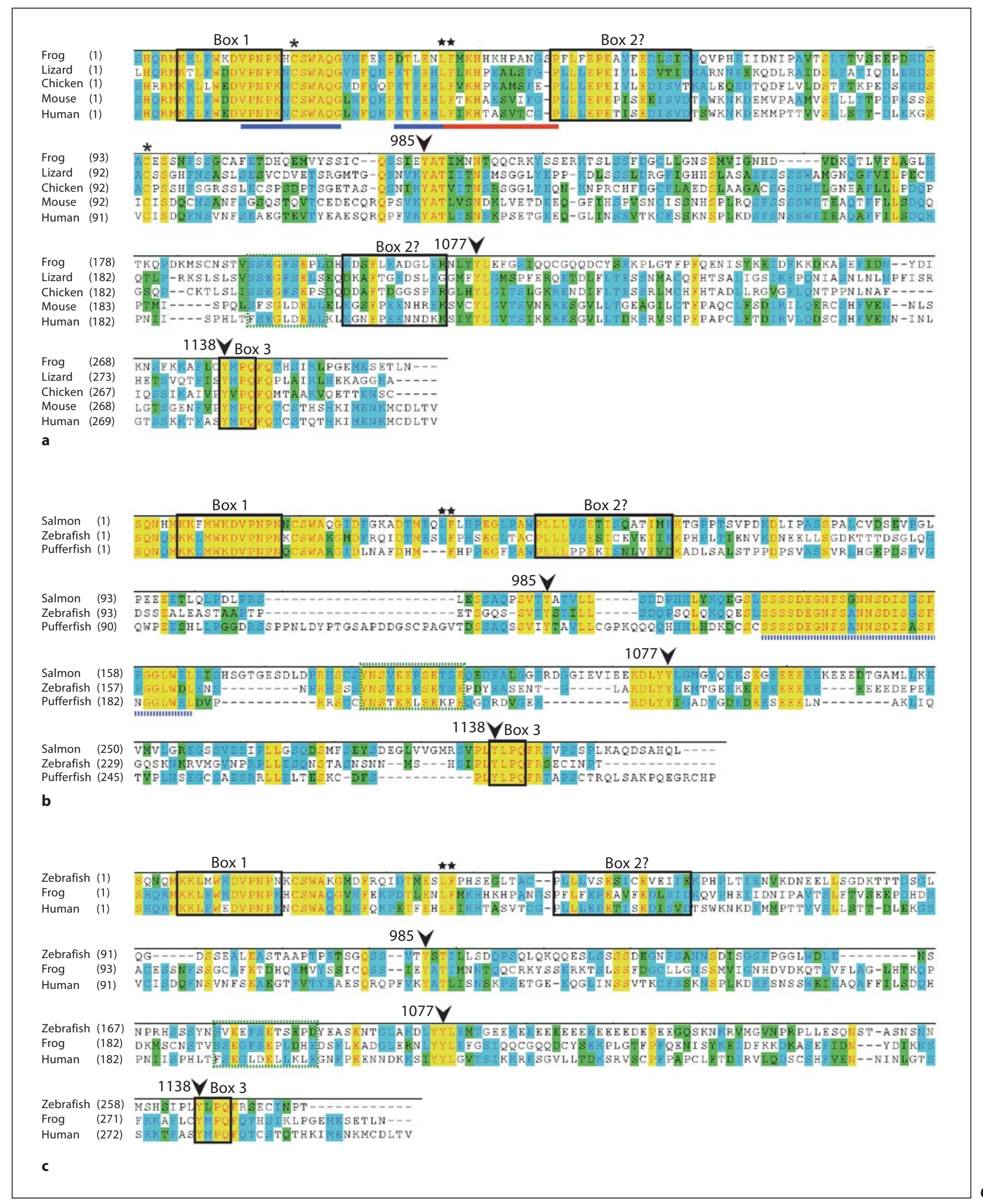


frog brain), ventral hypothalamus and anterior pituitary gland [C. Hu and R.J. Denver, unpublished]. Similar to mammals, LepR mRNA is found in many different tissues in ectotherms $[30,63,122]$ supporting that the hormone has the potential to have diverse influences on development and physiology. In the frog, LepR mRNA is highly expressed in brain, but of all tissues analyzed, LepR mRNA was highest in the pituitary gland [30], and leptin increased pSTAT3 immunoreactivity in the frog pituitary [C. Hu and R.J. Denver, unpublished]. These findings suggest that leptin could play a role in pituitary development and/or function [97].

\section{Evolutionary Conservation of Leptin Actions on Food Intake and Metabolism}

The major site of leptin action in mammals is the brain where it acts to inhibit appetite and increase energy expenditure $[123,124]$. Leptin influences energy balance through its primary actions on hypothalamic feeding and autonomic control centers, and secondarily through its influence on hypothalamo-pituitary-adrenal (HPA) and hypothalamo-pituitary-thyroid (HPT) axes [46, 125, 126].

Before Lep genes were isolated from nonmammalian species, injections of recombinant mouse (or 'chicken') leptin into chickens was found to reduce food intake in one study [127] but not another [128]. In a lizard, injections of mouse leptin reduced food intake and increased metabolic rate [77]. Mouse leptin inhibited food intake in the goldfish [129] but not in other fishes (e.g. coho salmon, catfish, and green sunfish; [27]). Although these findings pointed to a similar role for leptin in the regulation of food intake and energy metabolism in nonmammals as in mammals, the use of heterologous hormone and the conflicting results obtained in different species prohibited definitive conclusions.

Recent comparative studies in nonmammalian species using homologous leptin preparations support an ancient role for leptin in regulating food intake and metabolism $[30-32,130]$. The first demonstration of an anorexigenic effect of a homologous leptin in a nonmammalian species was shown in the frog, Xenopus laevis [30]. Intracerebroventricular injections of recombinant frog leptin (rxLeptin) in juvenile frogs strongly inhibited food intake, and this action developed in the tadpole during prometamorphosis. As in mammals, chronic administration of recombinant frog leptin reduced body weight of prometamorphic tadpoles [30]. Also, frog leptin injections caused food-deprived tadpoles to lose more weight than vehicle-injected controls, thus showing that leptin increases energy expenditure in prometamorphic tadpoles as it does in mammals. Murashita and colleagues [31, 130] showed that injections of recombinant rainbow trout leptin into trout decreased growth, inhibited feeding, decreased hypothalamic neuropeptide $\mathrm{Y}$ mRNA, and increased hypothalamic POMC mRNA. Li et al. [32] reported an anorexigenic effect of injected recombinant grass carp leptin on food intake in the carp.

\section{Nutritional Regulation of Leptin and Leptin's Role in Body Weight Regulation}

In mammals, leptin is secreted in proportion to fat stores and thus signals to the brain long-term energy balance $[131,132]$. Fasting decreases plasma leptin concentration, while refeeding reverses this decline. Little information is available in nonmammalian species relating nutrition to leptin production. In carp, hepatic Lep mRNA levels were increased after feeding but did not change during long-term fasting [57]. The only nonmammalian species for which a leptin radioimmunoassay has been developed is the rainbow trout [133]. Paradoxically, plasma leptin concentration was elevated during fasting in rainbow trout [133]. This led the authors to conclude that the regulation of circulating leptin concentration in fish differs from mammals, and that leptin may not function as an adiposity signal in fish (at least not in salmonids). However, the fact that leptin injections inhibit appetite in nonmammals suggests that it can signal to the brain information about energy balance, and so more work needs to be done to test the hypothesis that leptin functions as an adipostat in nonmammalian species.

\section{Summary and Directions for Future Research}

Recent molecular cloning and functional studies have increased our understanding of the diversity of functions and evolutionary history of the hormone leptin. Despite low primary amino acid sequence conservation, leptins from diverse species are predicted to form similar tertiary structures and bind to the LepR, which leads to activation of common intracellular signaling pathways via highly conserved structural motifs located within the LepR cytoplasmic domain.

A major role for leptin in mammals is as an adiposity signal, acting on the hypothalamus to suppress food intake and increase metabolic energy expenditure. Leptin's actions on the brain are mediated by the long form leptin 
receptor (LepRb), which leads to the activation of central melanocortin pathways that inhibit feeding. Similar actions of leptin on feeding have been discovered in nonmammalian species, although the hypothesis that leptin functions as an adiposity signal in nonmammals remains to be tested.

In mammals, leptin is an important indicator of body condition/nutritional state, signaling available energy for development, growth, and metabolism. Insufficient energy stores delay animal growth and development, and leptin's role as an adipostat suggests that it can influence the timing of energy-requiring developmental processes such as reproductive maturation (puberty in mammals) [96, 134, 135]. Females must achieve a minimum body size and body condition (i.e. fat stores) to initiate puberty. Leptin may play similar roles in nonmammalian species, signaling appropriate timing for developmental processes such as metamorphosis, a critical life history transition, and the onset of reproductive maturity, an energetically expensive process.

Findings of links between birth weight and adult onset metabolic disorders have focused on the relationships among leptin, growth and development during embryonic and fetal stages [136-140]. Circulating leptin is elevated in the human fetus during late gestation and cor- relates with fat mass and birth weight [141, 142]. Before the formation of adipose tissue, leptin and LepR are expressed in liver, heart, hair follicles, and primordial bone of fetal mouse [94, 143], and leptin is found in the circulation of fetal sheep [144]. Plasma leptin exhibits a surge during early postnatal development in rodents, and recent findings suggest that leptin plays an important role in controlling neurogenesis, and the maturation of feeding circuits in the hypothalamus [124]. Lep mRNA is expressed in frog oocytes and embryos before feeding stages and before adipose tissue formation [30]. LepR mRNA is expressed in tadpole hind limb, and injections of recombinant frog leptin accelerated hind limb development [30]. Thus, in addition to its integral role as a regulator of appetite and energy balance in juveniles and adults, these findings highlight the potential for important roles for leptin during early development.

\section{Acknowledgements}

The preparation of this paper was supported by NSF grant IOS 0641587 to RJD. We are grateful to four reviewers whose helpful comments improved the paper.

\section{References}

1 Coleman DL: A historical perspective on leptin. Nat Med 2010;16:1097-1099.

$\checkmark 2$ Coleman DL: Effects of parabiosis of obese with diabetes and normal mice. Diabetologia 1973;9:294-298.

-3 Coleman DL: Obese and diabetes - 2 mutant genes causing diabetes-obesity syndromes in mice. Diabetologia 1978; 14:141-148.

4 Zhang YY, Proenca R, Maffei M, Barone M, Leopold L, Friedman JM: Positional cloning of the mouse obese gene and its human homolog. Nature 1994;372:425-432.

5 Huising MO, Kruiswijk CP, Flik G: Phylogeny and evolution of class-I helical cytokines. J Endocrinol 2006;189:1-25.

-6 Tartaglia LA, Dembski M, Weng X, Deng $\mathrm{NH}$, Culpepper J, Devos R, Richards GJ, Campfield LA, Clark FT, Deeds J, Muir C, Sanker S, Moriarty A, Moore KJ, Smutko JS, Mays GG, WoolfEA, Monroe CA, Tepper RI: Identification and expression cloning of a leptin receptor, OB-R. Cell 1995;83:12631271.

\footnotetext{
Chen H, Charlat O, Tartaglia LA, Woolf EA, 14 Richard D, Carpentier AC, Dore G, Ouellet Weng X, Ellis SJ, Lakey ND, Culpepper J, Moore KJ, Breitbart RE, Duyk GM, Tepper RI, Morgenstern JP: Evidence that the diabetes gene encodes the leptin receptor: identification of a mutation in the leptin receptor gene in $d b / d b$ mice. Cell 1996;84:491-495.

8 Lee GH, Proenca R, Montez JM, Carroll KM, Darvishzadeh JG, Lee JI, Friedman JM: Abnormal splicing of the leptin receptor in diabetic mice. Nature 1996;379:632-635. V, Picard F: Determinants of brown adipocyte development and thermogenesis. Int J Obes 2010;34:S59-S66.

15 Friedman JM: Modern science versus the stigma of obesity. Nat Med 2004;10:563-569.

16 Friedman JM: Obesity in the new millennium. Nature 2000;404:632-634.

17 Friedman JM: A war on obesity, not the obese. Science 2003;299:856-858.

$\checkmark 9$ Pelleymounter MA, Cullen MJ, Baker MB, Hecht R, Winters D, Boone T, Collins F: Effects of the obese gene-product on bodyweight regulation in $o b / o b$ mice. Science 1995;269:540-543.

10 Ahima RS: Central actions of adipocyte hormones. Trends Endocrinol Metab 2005; 16 : 307-313.

11 Chehab FF, Mounzih K, Lu RH, Lim ME: Early onset of reproductive function in normal female mice treated with leptin. Science 1997;275:88-90.

12 Ahima RS, Osei SY: Leptin signaling. Physiol Behav 2004;81:223-241.

13 Maya-Monteiro CM, Bozza PT: Leptin and

18 Blakemore AIF, Froguel P: Is obesity our genetic legacy? J Clin Endocrinol Metab 2008; 93:S51-S56.

19 Myers MG, Leibel RL, Seeley RJ, Schwartz MW: Obesity and leptin resistance: Distinguishing cause from effect. Trends Endocrinol Metab 2010;21:643-651.

-20 Ahima RS, Saper CB, Flier JS, Elmquist JK: Leptin regulation of neuroendocrine systems. Front Neuroendocrinol 2000;21:263307.

-21 Elmquist JK, Coppari R, Balthasar N, Ichinose M, Lowell BB: Identifying hypothalamic pathways controlling food intake, body weight, and glucose homeostasis. J Comp Neurol 2005;493:63-71.
} mTOR. Cell Cycle 2008;7:1713-1717. 
-22 Baskin DG, Hahn TM, Schwartz MW: Leptin sensitive neurons in the hypothalamus. Horm Metab Res 1999;31:345-350.

-23 Elmquist JK, Ahima RS, Elias CF, Flier JS, Saper CB: Leptin activates distinct projections from the dorsomedial and ventromedial hypothalamic nuclei. Proc Natl Acad Sci USA 1998;95:741-746.

24 Elias CF, Aschkenasi C, Lee C, Kelly J, Ahima RS, Bjorbaek C, Flier JS, Saper CB, Elmquist JK: Leptin differentially regulates NPY and POMC neurons projecting to the lateral hypothalamic area. Neuron 1999;23: 775-786.

25 Bates SH, Myers MG: The role of leptin receptor signaling in feeding and neuroendocrine function. Trends Endocrinol Metab 2003; 14:447-452

26 Leinninger GM, Myers MG: LRb signals act within a distributed network of leptin-responsive neurones to mediate leptin action. Acta Physiol 2008;192:49-59.

-27 Volkoff H, Canosa LF, Unniappan S, CerdaReverter JM, Bernier NJ, Kelly SP, Peter RE: Neuropeptides and the control of food intake in fish. Gen Comp Endocrinol 2005; 142:319.

28 Crespi EJ, Denver RJ: Roles of stress hormones in food intake regulation in anuran amphibians throughout the life cycle. Comp Biochem Physiol A Comp Physiol 2005; 141 381-390.

29 Carr JA: Stress, neuropeptides, and feeding behavior: a comparative perspective. Int Comp Biol 2002;42:582-590.

-30 Crespi EJ, Denver RJ: Leptin (ob gene) of the South African clawed frog Xenopus laevis. Proc Natl Acad Sci USA 2006;103:1009210097.

-31 Murashita K, Uji S, Yamamoto T, Ronnestad I, Kurokawa T: Production of recombinant leptin and its effects on food intake in rainbow trout (Oncorhynchus mykiss). Comp Biochem Physiol B Biochem Mol Biol 2008; 150:377-384

- 32 Li GG, Liang XF, Xie QL, Li GZ, Yu Y, Lai KS: Gene structure, recombinant expression and functional characterization of grass carp leptin. Gen Comp Endocrinol 2010;166:117127.

33 Gat-Yablonski G, Phillip M: Leptin and regulation of linear growth. Curr Opin Clin Nutr Metab Care 2008;11:303-308.

34 Roa JA, Tena-Sempere M: Energy balance and puberty onset: emerging role of central mTOR signaling. Trends Endocrinol Metab 2010;21:519-528.

-35 Steppan CM, Swick AG: A role for leptin in brain development. Biochem Biophys Res Commun 1999;256:600-602.

- 36 Udagawa J, Hashimoto R, Suzuki H, Hatta T, Sotomaru Y, Hioki K, Kagohashi Y, Nomura T, Minami Y, Otani H: The role of leptin in the development of the cerebral cortex in mouse embryos. Endocrinology 2006; 147: 647-658.
Udagawa J, Hatta T, Hashimoto R, Otani $\mathrm{H}$ : Roles of leptin in prenatal and perinatal brain development. Congen Anomal 2007; 47:77-83.

38 Bouret SG, Simerly RB: Development of leptin-sensitive circuits. J Neuroendocrinol 2007;19:575-582.

39 Steppan CM, Crawford DT, Chidsey-Frink $\mathrm{KL}, \mathrm{Ke} H Z$, Swick AG: Leptin is a potent stimulator of bone growth in $o b / o b$ mice. Regulat Pept 2000;92:73-78.

40 Driessler F, Baldock PA: Hypothalamic regulation of bone. J Mol Endocrinol 2010;45: 175-181.

41 Karsenty G, Oury F: The central regulation of bone mass, the first link between bone remodeling and energy metabolism. J Clin Endocrinol Metab 2010;95:4795-4801.

42 Lee NK: An evolving integrative physiology: skeleton and energy metabolism. BMB Rep 2010;43:579-583

-43 Malli F, Papaioannou AI, Gourgoulianis KI, Daniil Z: The role of leptin in the respiratory system: an overview. Respir Res 2010;11:152.

44 Fantuzzi G: Three questions about leptin and immunity. Brain Behav Immun 2009;23: 405-410.

45 Procaccini C, Lourenco EV, Matarese G, La Cava A: Leptin signaling: a key pathway in immune responses. Curr Sig Transduc Ther 2009;4:22-30.

46 Ghamari-Langroudi M, Vella KR, Srisai D, Sugrue ML, Hollenberg AN, Cone RD: Regulation of thyrotropin-releasing hormoneexpressing neurons in paraventricular nucleus of the hypothalamus by signals of adiposity. Mol Endocrinol 2010;24:2366-2381.

47 Doyon C, Trudeau VL, Hibbert BM, Howes LA, Moon TW: mRNA analysis in flattened fauna: obtaining gene-sequence information from road-kill and game-hunting samples. Can J Zool 2003;81:692-698.

- 48 Doyon C, Drouin G, Trudeau VL, Moon TW: Molecular evolution of leptin. Gen Comp Endocrinol 2001;124:188-198.

49 Hammond JA, Bennett KA, Walton MJ, Hall AJ: Molecular cloning and expression of leptin in gray and harbor seal blubber, bone marrow, and lung and its potential role in marine mammal respiratory physiology. Am J Physiol Regul Integr Com Physiol 2005; 289:R545-R553

-50 Yang J, Wang ZL, Zhao XQ, Wang DP, Qi DL, Xu BH, Ren YH, Tian HF: Natural selection and adaptive evolution of leptin in the Ochotona family driven by the cold environmental stress. PLoS One 2008;3:e1472.

51 Taouis M, Chen JW, Daviaud C, Dupont J, Derouet M, Simon J: Cloning the chicken leptin gene. Gene 1998;208:239-242.

52 Ashwell CM, Czerwinski SM, Brocht DM, McMurtry JP: Hormonal regulation of leptin expression in broiler chickens. Am J Physiol Regul Integr Com Physiol 1999;276:R226R232.
Carre W, Wang XF, Porter TE, Nys Y, Tang JS, Bernberg E, Morgan R, Burnside J, Aggrey SE, Simon J, Cogburn LA: Chicken genomics resource: Sequencing and annotation of 35,407 ESTs from single and multiple tissue cDNA libraries and CAP3 assembly of a chicken gene index. Physiol Genomics 2006;25:514-524.

54 Friedman-Einat M, Boswell T, Horev G, Girishvarma G, Dunn IC, Talbot RT, Sharp PJ: The chicken leptin gene: has it been cloned? Gen Comp Endocrinol 1999;115: 354-363.

55 Sharp PJ, Dunn IC, Waddington D, Boswell T: Chicken leptin. Gen Comp Endocrinol 2008;158:2-4.

56 Pitel F, Faraut T, Bruneau G, Monget P: Is there a leptin gene in the chicken genome? Lessons from phylogenetics, bioinformatics and genomics. Gen Comp Endocrinol 2010; 167:1-5.

57 Huising MO, Geven EJW, Kruiswijk CP, Nabuurs SB, Stolte EH, Spanings FAT, Verburg-Van Kemenade BML, Flik G: Increased leptin expression in common carp (Cyprinus carpio) after food intake but not after fasting or feeding to satiation. Endocrinology 2006; 147:5786-5797.

58 Simon J, Rideau N, Taouis M: Reply to viewpoints by PJ Sharp, IC Dunn, D Waddington, and $\mathrm{T}$ Boswell [Chicken leptin: General and Comparative Endocrinology, 158, 2-4 (2008)]. Gen Comp Endocrinol 2009;161: 159.

59 Hen G, Yosefi S, Ronin A, Einat P, Rosenblum C, Denver RJ, Friedman-Einat M: Monitoring leptin activity via the chicken leptin receptor. J Endocrinol 2008;197:325333.

60 Kurokawa T, Uji S, Suzuki T: Identification of cDNA coding for a homologue to mammalian leptin from pufferfish, Takifugu rubripes. Peptides 2005;26:745-750.

61 Boswell T, Dunn IC, Wilson PW, Joseph N, Burt DW, Sharp PJ: Identification of a nonmammalian leptin-like gene: Characterization and expression in the tiger salamander (Ambystoma tigrinum). Gen Comp Endocrinol 2006;146:157-166.

- 62 Gorissen M, Bernier NJ, Nabuurs SB, Flik G Huising MO: Two divergent leptin paralogues in zebrafish (Danio rerio) that originate early in teleostean evolution. J Endocrinol 2009;201:329-339.

63 Rønnestad I, Nilsen TO, Murashita K, Angotzi AR, Gamst Moen AG, Stefansson SO, Kling P, Thrandur Björnsson B, Kurokawa T: Leptin and leptin receptor genes in Atlantic salmon: cloning, phylogeny, tissue distribution and expression correlated to long-term feeding status. Gen Comp Endocrinol 2010; 168:55-70.

64 Froiland E, Murashita K, Jorgensen EH, Kurokawa T: Leptin and ghrelin in anadromous arctic charr: cloning and change in expressions during a seasonal feeding cycle. Gen Comp Endocrinol 2010;165:136-143. 
65 Jaillon O, Aury JM, Brunet F, Petit JL, StangeThomann N, Mauceli E, Bouneau L, Fischer C, Ozouf-Costaz C, Bernot A, Nicaud S, Jaffe D, Fisher S, Lutfalla G, Dossat C, Segurens B, Dasilva C, Salanoubat M, Levy M, Boudet N, Castellano S, Anthouard R, Jubin C, Castelli V, Katinka M, Vacherie B, Biemont C, Skalli Z, Cattolico L, Poulain J, de Berardinis V, Cruaud C, Duprat S, Brottier P, Coutanceau JP, Gouzy J, Parra G, Lardier G, Chapple C, McKernan KJ, McEwan P, Bosak S, Kellis M, Volff JN, Guigo R, Zody MC, Mesirov J, Lindblad-Toh K, Birren B, Nusbaum C, Kahn D, Robinson-Rechavi M, Laudet V, Schachter V, Quetier F, Saurin W, Scarpelli C, Wincker P, Lander ES, Weissenbach J, Crollius HR: Genome duplication in the teleost fish Tetraodon nigroviridis reveals the early vertebrate proto-karyotype. Nature 2004;431:946-957.

-66 Phillips R, Rab P: Chromosome evolution in the salmonidae (Pisces): an update. Biol Rev Camb Philos Soc 2001;76:1-25.

67 Kurokawa T, Murashita K: Genomic characterization of multiple leptin genes and a leptin receptor gene in the Japanese medaka, Oryzias latipes. Gen Comp Endocrinol 2009; 161:229-237.

68 Allendorf Y, Thorgaard G: Tetraploidy and the evolution of salmonid fishes; in Turner B (ed): The Evolutionary Genetics of Fishes. New York, Plenum Press, 1984, pp 1-53.

69 Larhammar D, Risinger C: Molecular genetic aspects of tetraploidy in the common carp Cyprinus carpio. Mol Phylogen Evol 1994;3: 59-68.

-70 David L, Blum S, Feldman M, Lavi U, Hillel J: Recent duplication of the common carp (Cyprinus carpio 1.) genome as revealed by analyses of microsatellite loci. Mol Biol Evol 2003;20:1425-1434.

71 Boorse GC, Libbon JV: Genomic characterization of two leptin genes and a leptin receptor gene in the Green Anole, Anolis carolinensis. Int Comp Biol 2010;50:E207.

-72 Paolucci M, Buono S, Sciarrillo R, Putti R: Effects of leptin administration on the endocrine pancreas and liver in the lizard Podarcis sicula. J Exp Zool A Comp Exp Biol 2006; 305A:383-395.

-73 Spanovich S, Niewiarowski PH, Londraville RL: Seasonal effects on circulating leptin in the lizard Sceloporus undulatus from two populations. Comp Biochem Physiol B Biochem Mol Biol 2006; 143:507-513.

-74 Sciarrillo R, Virgilio F, De Falco M, Laforgia V, Varano L, Paolucci M: Localization and role of leptin in the thyroid gland of the lizard Podarcis sicula (Reptilia, Lacertidae). J Exp Zool A Comp Exp Biol 2005;303A:628634.

-75 Muruzabal FJ, Fruhbeck G, Gomez-Ambrosi J, Archanco M, Burrell MA: Immunocytochemical detection of leptin in non-mammalian vertebrate stomach. Gen Comp Endocrinol 2002;128:149-152.
6 Paolucci M, Rocco M, Varricchio E: Leptin presence in plasma, liver and fat bodies in the lizard Podarcissicula - fluctuations throughout the reproductive cycle. Life Sciences 2001;69:2399-2408.

77 Niewiarowski PH, Balk ML, Londraville RL: Phenotypic effects of leptin in an ectotherm: A new tool to study the evolution of life histories and endothermy? J Exp Biol 2000;203: 295-300.

78 Johnson RM, Johnson TM, Londraville RL: Evidence for leptin expression in fishes. J Exp Zool 2000;286:718-724.

79 Gambardella C, Ferrando S, Ferrando T, Ravera S, Gallus L, Fasulo S, Tagliafierro G: Immunolocalisation of leptin in the digestive system of juvenile European sea bass (Dicentrarchus labrax). Ital J Zool 2010;77:391-398.

80 Gambardella C, Ferrando S, Gallus L, Ravera S, Bianchini P, Ramoino P, Fasulo S, Tagliafierro G: Leptin-like immunoreactivity in the muscle of juvenile sea bass (Dicentrarchus labrax). Micros Res Tech 2010;73:797-802.

81 Pfundt B, Sauerwein H, Mielenz M: Leptin mRNA and protein immunoreactivity in adipose tissue and liver of rainbow trout $(\mathrm{On}$ corhynchus mykiss) and immunohistochemical localization in liver. Anat Histol Embryol 2009;38:406-410.

82 Yacobovitz M, Solomon G, Gusakovsky EE, Levavi-Sivan B, Gertler A: Purification and characterization of recombinant pufferfish (Takifugu rubripes) leptin. Gen Comp Endocrinol 2008;156:83-90.

83 French S, Robson B: What is a conservative substitution? J Mol Evol 1983;19:171-175.

84 Imagawa K, Numata Y, Katsuura G, Sakaguchi I, Morita A, Kikuoka S, Matumoto Y, Tsuji T, Tamaki M, Sasakura K, Teraoka H, Hosoda K, Ogawa Y, Nakao K: Structurefunction studies of human leptin. J Biol Chem 1998;273:35245-35249.

85 Peelman F, Van Beneden K, Zabeau L, Iserentant $\mathrm{H}$, Ulrichts $\mathrm{P}$, Defeau $\mathrm{D}$, Verhee $\mathrm{A}$, Catteeuw D, Elewaut D, Tavernier J: Mapping of the leptin binding sites and design of a leptin antagonist. J Biol Chem 2004;279: 41038-41046.

86 Gertler A: Development of leptin antagonists and their potential use in experimental biology and medicine. Trends Endocrinol Metab 2006;17:372-378.

87 Elinav E, Niv-Spector L, Katz M, Price TO, Ali M, Yacobovitz M, Solomon G, Reicher S, Lynch JL, Halpern Z, Banks WA, Gertler A: Pegylated leptin antagonist is a potent orexigenic agent: Preparation and mechanism of activity. Endocrinology 2009;150:3083-3091.

- 88 Peelman F, Iserentant H, De Smet AS, Vandekerckhove J, Zabeau L, Tavernier J: Mapping of binding site iii in the leptin receptor and modeling of a hexameric leptin center-leptin receptor complex. J Biol Chem 2006;281: 15496-15504.

89 Friedman JM: Leptin, leptin receptors, and the control of body weight. Nutr Rev 1998; $56: S 38-S 46$.
90 Bado A, Levasseur S, Attoub S, Kermorgant S, Laigneau JP, Bortoluzzi MN, Moizo L, Lehy T, Guerre-Millo M, Le MarchandBrustel Y, Lewin MJM: The stomach is a source of leptin. Nature 1998;394:790-793.

-91 Ikejima K, Takei Y, Honda H, Hirose M, Yoshikawa M, Zhang YJ, Lang T, Fukuda T, Yamashina S, Kitamura T, Sato N: Leptin receptor-mediated signaling regulates hepatic fibrogenesis and remodeling of extracellular matrix in the rat. Gastroenterology 2002;122:1399-1410.

-92 Potter JJ, Womack L, Mezey E, Anania FA: Transdifferentiation of rat hepatic stellate cells results in leptin expression. Biochem Biophys Res Commun 1998;244:178-182.

93 Green ED, Maffei M, Braden VV, Proenca R, Desilva U, Zhang YY, Chua SC, Leibel RL, Weissenbach J, Friedman JM: The human obese $(o b)$ gene - RNA expression pattern and mapping on the physical, cytogenetic, and genetic maps of chromosome-7. Genome Res 1995;5:5-12.

-94 Hoggard N, Hunter L, Duncan JS, Williams LM, Trayhurn P, Mercer JG: Leptin and leptin receptor mRNA and protein expression in the murine fetus and placenta. Proc Natl Acad Sci USA 1997;94:11073-11078.

$\checkmark 95$ Clement K, Vaisse C, Lahlou N, Cabrol S, Pelloux V, Cassuto D, Gourmelen M, Dina C, Chambaz J, Lacorte JM, Basdevant A, Bougneres P, Lebouc Y, Froguel P, GuyGrand B: A mutation in the human leptin receptor gene causes obesity and pituitary dysfunction. Nature 1998;392:398-401.

96 Cervero A, Dominguez F, Horcajadas JA, Quinonero A, Pellicer A, Simon C: The role of the leptin in reproduction. Curr Opin Obstet Gynecol 2006;18:297-303.

-97 Tipsmark CK, Strom CN, Bailey ST, Borski RJ: Leptin stimulates pituitary prolactin release through an extracellular signal-regulated kinase-dependent pathway. J Endocrinol 2008;196:275-281.

98 Harvey J: Leptin - a multifaceted hormone in the central nervous system. Mol Neurobiol 2003;28:245-258.

-99 Bouret SG, Draper SJ, Simerly RB: Trophic action of leptin on hypothalamic neurons that regulate feeding. Science 2004;304: 108-110.

100 Bouret SG, Simerly RB: Minireview: leptin and development of hypothalamic feeding circuits. Endocrinology 2004; 145:26212626.

101 Harvey J, Shanley LJ, O’Malley D, Irving AJ: Leptin: A potential cognitive enhancer? Biochem Soc Trans 2005;33:1029-1032.

102 Liongue C, Ward AC: Evolution of class I cytokine receptors. BMC Evol Biol 2007;7: 120.

103 O'Sullivan LA, Liongue C, Lewis RS, Stephenson SEM, Ward AC: Cytokine receptor signaling through the JAK-STAT-SOCS pathway in disease. Mol Immunol 2007;44: 2497-2506. 
104 Villanueva EC, Myers MG: Leptin receptor signaling and the regulation of mammalian physiology. Int J Obes 2008;32:S8-S12.

-105 Gorissen M, de Vrieze E, Flik G, Huising M: STAT genes display differential evolutionary rates that correlate with their roles in the endocrine and immune system. J Endocrinol 2011;209:175-184.

- 106 Liu XJ, Dunn IC, Sharp PJ, Boswell T: Molecular cloning and tissue distribution of a short form chicken leptin receptor mRNA. Domest Anim Endocrinol 2007;32:155166.

$\checkmark 107$ Kloek C, Haq AK, Dunn SL, Lavery HJ, Banks AS, Myers MG: Regulation of Jak kinases by intracellular leptin receptor sequences. J Biol Chem 2002;277:4154741555.

- 108 Bahrenberg G, Behrmann I, Barthel A, Hekerman P, Heinrich PC, Joost HG, Becker W: Identification of the critical sequence elements in the cytoplasmic domain of leptin receptor isoforms required for Janus kinase/signal transducer and activator of transcription activation by receptor heterodimers. Mol Endocrinol 2002;16:859872.

109 Taga T, Kishimoto T: Gp130 and the interleukin- 6 family of cytokines. Ann Rev Immunol 1997;15:797-819.

-110 White DW, Kuropatwinski KK, Devos R, Baumann H, Tartaglia LA: Leptin receptor (OB-R) signaling - cytoplasmic domain mutational analysis and evidence for receptor homo-oligomerization. J Biol Chem 1997;272:4065-4071.

-111 Banks AS, Davis SM, Bates SH, Myers MG: Activation of downstream signals by the long form of the leptin receptor. J Biol Chem 2000;275:14563-14572.

-112 Carpenter LR, Farruggella TJ, Symes A, Karow ML, Yancopoulos GD, Stahl N: Enhancing leptin response by preventing SH2-containing phosphatase 2 interaction with $o b$ receptor. Proc Natl Acad Sci USA 1998;95:6061-6066.

-113 Li C, Friedman JM: Leptin receptor activation of $\mathrm{SH} 2$ domain containing protein tyrosine phosphatase 2 modulates $o b$ receptor signal transduction. Proc Natl Acad Sci USA 1999;96:9677-9682.

- 114 Bjorbaek C, Lavery HJ, Bates SH, Olson RK, Davis SM, Flier JS, Myers MG: SOCS3 mediates feedback inhibition of the leptin receptor via $\operatorname{Tyr}(985)$. J Biol Chem 2000;275: 40649-40657.

- 115 Gong Y, Ishida-Takahashi R, Villanueva EC, Fingar DC, Muenzberg H, Myers MG: The long form of the leptin receptor regulates STAT5 and ribosomal protein S6 via alternate mechanisms. J Biol Chem 2007; 282:31019-31027.

- 116 Bates SH, Kulkarni RN, Seifert M, Myers MG: Roles for leptin receptor/STAT3-dependent and -independent signals in the regulation of glucose homeostasis. Cell Metab 2005;1:169-178.
117 Fei H, Okano HJ, Li C, Lee GH, Zhao C, Darnell R, Friedman JM: Anatomic localization of alternatively spliced leptin receptors (OB-R) in mouse brain and other tissues. Proc Natl Acad Sci USA 1997;94:70017005.

- 118 Sobhani I, Bado A, Vissuzaine C, Buyse M, Kermorgant S, Laigneau JP, Attoub S, Lehy T, Henin D, Mignon M, Lewin MJM: Leptin secretion and leptin receptor in the human stomach. Gut 2000;47:178-183.

119 Covey SD, Wideman RD, McDonald C, Unniappan S, Huynh F, Asadi A, Speck M, Webber T, Chua SC, Kieffer TJ: The pancreatic beta cell is a key site for mediating the effects of leptin on glucose homeostasis. Cell Metab 2006;4:291-302.

120 Lord GM, Matarese G, Howard LK, Baker RJ, Bloom SR, Lechler RI: Leptin modulates the T-cell immune response and reverses starvation-induced immunosuppression. Nature 1998;394:897-901.

121 Cohen P, Zhao C, Cai XL, Montez JM, Rohani SC, Feinstein P, Mombaerts P, Friedman JM: Selective deletion of leptin receptor in neurons leads to obesity. J Clin Invest 2001;108:1113-1121.

122 Liu Q, Chen Y, Copeland D, Ball H, Duff RJ, Rockich B, Londraville RL: Expression of leptin receptor gene in developing and adult zebrafish. Gen Comp Endocrinol 2010; 166:346-355.

123 Neary NM, Goldstone AP, Bloom SR: Appetite regulation: from the gut to the hypothalamus. Clin Endocrinol 2004;60:153160.

124 Myers MG, Simerly RB: The neuroendocrinology and neuroscience of energy balance. Front Neuroendocrinol 2010;31:1-3.

125 Cohen MM: Role of leptin in regulating appetite, neuroendocrine function, and bone remodeling. Am J Med Genet A 2006; 140A:515-524.

126 Woods AJ, Stock MJ: Leptin activation in hypothalamus. Nature 1996;381:745.

127 Taouis M, Dridi S, Cassy S, Benomar Y, Raver N, Rideau N, Picard M, Williams J, Gertler A: Chicken leptin: properties and actions. Domest Anim Endocrinol 2001;21:319-327.

- 128 Bungo T, Shimojo M, Masuda Y, Tachibanab T, Tanaka SJ, Sugahara K, Furuse M: Intracerebroventricular administration of mouse leptin does not reduce food intake in the chicken. Brain Res 1999;817:196-198.

129 Volkoff H, Eykelbosh AJ, Peter RE: Role of leptin in the control of feeding of goldfish Carassius auratus: interactions with cholecystokinin, neuropeptide $\mathrm{Y}$ and orexin $\mathrm{A}$, and modulation by fasting. Brain Res 2003; 972:90-109.

130 Murashita K, Jordal A-EO, Nilsen TO, Stefansson SO, Kurokawa T, Bjornsson BT, Moen A-GG, Ronnestad I: Leptin reduces atlantic salmon growth through the central pro-opiomelanocortin pathway. Comp Biochem Physiol A Mol Integr Physiol 2011; 158:79-86.
131 Friedman JM, Halaas JL: Leptin and the regulation of body weight in mammals. Nature 1998;395:763-770.

132 Friedman JM: The function of leptin in nutrition; weight, and physiology. Nutrition Rev 2002;60:S1-S14.

133 Kling P, Ronnestad I, Stefansson SO, Murashita K, Kurokawa T, Bjornsson BT: A homologous salmonid leptin radioimmunoassay indicates elevated plasma leptin levels during fasting of rainbow trout. Gen Comp Endocrinol 2009;162:307-312.

134 Cheung CC, Thornton JE, Kuijper JL, Weigle DS, Clifton DK, Steiner RA: Leptin is a metabolic gate for the onset of puberty in the female rat. Endocrinology 1997;138: 855-858.

135 Martos-Moreno GA, Chowen JA, Argente J: Metabolic signals in human puberty: Effects of over and undernutrition. Mol Cell Endocrinol 2010;324:70-81.

136 Barker DJ, Clark PM: Fetal undernutrition and disease later in life. Rev Reprod 1997;2: 105-112.

137 Prentice AM: Early influences on human energy regulation: Thrifty genotypes and thrifty phenotypes. Physiol Behav 2005;86: 640-645.

138 McMillen IC, Adam CL, Muhlhausler BS: Early origins of obesity: programming the appetite regulatory system. J Physiol Lond 2005;565:9-17.

139 McMillen IC, Edwards LJ, Duffield J, Muhlhausler BS: Regulation of leptin synthesis and secretion before birth: implications for the early programming of adult obesity. Reproduction 2006;131:415-427.

140 Tamashiro KLK, Moran TH: Perinatal environment and its influences on metabolic programming of offspring. Physiol Behav 2010;100:560-566.

141 Lepercq J, Challier JC, Guerre-Millo M, Cauzac M, Vidal H, Hauguel-de Mouzon S: Prenatal leptin production: evidence that fetal adipose tissue produces leptin. J Clin Endocrinol Metab 2001;86:2409-2413.

142 Cetin I, Morpurgo PS, Radaelli T, Taricco E, Cortelazzi D, Bellotti M, Pardi G, BeckPeccoz P: Fetal plasma leptin concentrations: Relationship with different intrauterine growth patterns from 19 weeks to term. Pediatric Research 2000;48:646-651.

143 Hoggard N, Hunter L, Lea RG, Trayhurn P, Mercer JG: Ontogeny of the expression of leptin and its receptor in the murine fetus and placenta. Br J Nutr 2000;83:317-326.

144 Ehrhardt RA, Bell AW, Boisclair YR: Spatial and developmental regulation of leptin in fetal sheep. Am J Physiol Regul Integr Com Physiol 2002;282:R1628-R1635.

145 Zhang FM, Basinski MB, Beals JM, Briggs SL, Churgay LM, Clawson DK, DiMarchi RD, Furman TC, Hale JE, Hsiung HM, Schoner BE, Smith DP, Zhang XY, Wery JP, Schevitz RW: Crystal structure of the obese protein leptin-e100. Nature 1997;387:206209. 